Article

\title{
Biosorption of $\mathrm{Co}^{2+}$ Ions from Aqueous Solution by $\mathrm{K}_{2} \mathrm{HPO}_{4}$-Pretreated Duckweed Lemna gibba
}

\author{
Jessica Lizeth Reyes-Ledezma, Eliseo Cristiani-Urbina $₫$ and Liliana Morales-Barrera * \\ Departamento de Ingeniería Bioquímica, Escuela Nacional de Ciencias Biológicas, Instituto Politécnico Nacional, \\ Av. Wilfrido Massieu s/n, Unidad Profesional Adolfo López Mateos, Ciudad de Mexico 07738, Mexico; \\ jessicalrl22@hotmail.com (J.L.R.-L.); ecristianiu@yahoo.com.mx (E.C.-U.) \\ * Correspondence: lmoralesb@ipn.mx; Tel.: +52-55-5729-6000 (ext. 57827)
}

Received: 19 October 2020; Accepted: 23 November 2020; Published: 25 November 2020

\begin{abstract}
The wastewater of the many industries that use divalent cobalt $\left(\mathrm{Co}^{2+}\right)$-containing compounds has elevated levels of this metal. Thus, novel technology is needed to efficiently remove $\mathrm{Co}^{2+}$ ions from aqueous solutions. Biosorption is a low-cost technique capable of removing heavy metals from contaminated water. This study aims to evaluate the performance of $\mathrm{KH}_{2} \mathrm{PO}_{4}$-pretreated Lemna gibba (PLEM) as a biosorbent of $\mathrm{Co}^{2+}$ in aqueous solutions tested under different conditions of $\mathrm{pH}$, particle size, and initial $\mathrm{Co}^{2+}$ concentration. Kinetic, equilibrium, and thermodynamic studies were conducted. The capacity of biosorption increased with a greater initial $\mathrm{Co}^{2+}$ concentration and was optimal at pH 7.0 and with small-sized biosorbent particles $(0.3-0.8 \mathrm{~mm})$. The pseudo-second-order sorption model best describes the experimental data on $\mathrm{Co}^{2+}$ biosorption kinetics. The Sips and Redlich-Peterson isotherm models best predict the biosorption capacity at equilibrium. According to the thermodynamic study, biosorption of $\mathrm{Co}^{2+}$ was endothermic and spontaneous. The effect of $\mathrm{pH}$ on the biosorption/desorption of $\mathrm{Co}^{2+}$ suggests that electrostatic attraction is the main biosorption mechanism. SEM-EDX verified the presence of $\mathrm{Co}^{2+}$ on the surface of the pretreated-saturated biosorbent and the absence of the metal after desorption.
\end{abstract}

Keywords: divalent cobalt; Lemna gibba; biosorption; desorption; SEM-EDX

\section{Introduction}

Excessive population growth, urbanization, and industrial development have increased the pollution of the planet and altered ecosystems. Of all environmental pollution, the contamination of water is the most worrisome because of affecting the primordial element on which life is based. The main source of water pollution is the discharge of industrial wastewater with diverse toxic substances, among which heavy metals are of particular concern [1].

Cobalt is a heavy metal found in the Earth's crust, being a natural component of volcanic emissions, as well as surface and subterranean water. It is released into the environment through anthropogenic activities: Burning fossil fuels, applying fertilizers, mining, electroplating, manufacturing batteries, and producing commodities with industrial processes involving cobalt-containing compounds, among others.

Although cobalt is an essential nutrient in human metabolism and the principal component of vitamin B12 [2], it is harmful to our health beyond trace levels, competing with other elements that constitute integral parts of a proper metabolic function [3]. In excess, it can give rise to skin irritation and problems in bone development, as well as respiratory, cardiac, thyroid, liver, and gastric disorders $[4,5]$. Due to being hazardous to humans and ecosystems [6], cobalt-contaminated wastewater should be treated prior to being released into the environment. 
Since low concentrations of cobalt are difficult to remove from water by conventional physicochemical treatments, it is necessary to apply innovative technology characterized by safety, efficiency, and versatility. One alternative is biosorption, a process independent of cell metabolism [7]. This technique, which has been little studied as a remedy for $\mathrm{Co}^{2+}$ pollution, can be carried out by living, dead, or inactive biological material [8,9].

Biosorption is a process of capturing heavy metals by physical adsorption (physisorption), ionic interchange, chemisorption (e.g., complexation, coordination, and chelation), and microprecipitation [10]. Diverse biological materials are capable of biosorption, including agroindustrial waste, microbial biomass, and biopolymers. These economical materials are available in great quantities, and the respective processes are environmentally friendly $[11,12]$. Unlike physicochemical methods, biosorption techniques can efficiently remove low concentrations of metals from aqueous solutions. If biosorption is followed by desorption, the metals can be recovered and the biosorbents regenerated for later use [13].

The current contribution focuses on the biosorbent potential of Lemna gibba, a macrophyte of universal distribution commonly known as duckweed. This plant, which quickly proliferates to double its biomass in about two days, lends itself to the bioremediation of aquatic systems, due to its small size $(2-4 \mathrm{~mm})$ and ability to bioaccumulate toxic compounds (e.g., heavy metals) [14]. Because eutrophication has provoked an excessive spread of Lemna gibba, it is now a plague in many places. Its excessive growth in the form of a thick mat on the aquatic body leads to navigation problems, harbors harmful fauna, and prevents sunlight from reaching photosynthetic species in the water below, thus interrupting the correct oxygenation of its environment $[15,16]$. Apart from being abundantly available, the plant material holds promise as a sustainable biosorbent for treating wastewater contaminated with cobalt and other heavy metals.

According to a previous report, pretreatment of $L$. gibba with $\mathrm{K}_{2} \mathrm{HPO}_{4}$ substantially improves the availability of sorption sites on the surface of plant cells, and therefore, their capacity for $\mathrm{Co}^{2+}$ biosorption, which is achieved by removing salts and producing a higher negative charge ( $-35 \mathrm{vs}$. $-26 \mathrm{mV})$. The zero point of charge $\left(\zeta_{0}\right)$ was 2.37 for unpretreated and 1.62 for $\mathrm{K}_{2} \mathrm{HPO}_{4}$-pretreated Lemna gibba, thus creating a greater attraction in the latter for positively charged $\mathrm{Co}^{2+}$. The ATR-FTIR analysis of $\mathrm{K}_{2} \mathrm{HPO}_{4}$-pretreated Lemna gibba revealed an important role of its hydroxyl and carboxyl groups in the removal of $\mathrm{Co}^{2+}$ [17]. The aim of the present study was to analyze the performance of $\mathrm{K}_{2} \mathrm{HPO}_{4}$-pretreated L. gibba as a biosorbent under distinct conditions of $\mathrm{pH}$, particle size, and the initial concentration of $\mathrm{Co}^{2+}$. Various theoretical models were tested to find the best one for describing the experimental data on biosorption. To determine the best eluent solution for desorption, saturated L. gibba was processed with strong and weak acids, as well as some alkaline compounds. Considering that recyclability is a prerequisite for the practical application of biosorption technology, three biosorption/desorption cycles were herein evaluated.

\section{Materials and Methods}

\subsection{Reagents}

The reagents employed in the experiments were all of analytical grade (JT Baker ${ }^{\circledR}$, Monterrey, Mexico). During the biosorption experiments, the $\mathrm{pH}$ of the solutions was maintained constant by adding $\mathrm{HCl}$ and $\mathrm{NaOH}$ in the solution at a concentration of $0.1 \mathrm{M}$ and $0.01 \mathrm{M}$, respectively. The different concentrations of $\mathrm{Co}^{2+}$ were prepared by making dilutions of a stock solution of $\mathrm{CoCl}_{2} \cdot 6 \mathrm{H}_{2} \mathrm{O}(>98 \%$ purity) containing $1 \mathrm{~g} \mathrm{~L}^{-1}$ of $\mathrm{Co}^{2+}$.

\subsection{Preparation of the Biosorbent}

Lemna gibba was collected from the Xochimilco canals in Mexico City $\left(19^{\circ} 15^{\prime} 31.8^{\prime \prime} \mathrm{N} 99^{\circ} 05^{\prime} 05.3^{\prime \prime} \mathrm{W}\right)$. It was cleaned with running tap water and then deionized water before being dried in a Luzeren ${ }^{\circledR}$ oven (Proveedor de Laboratorios, Mexico) at $60^{\circ} \mathrm{C}$ for $48 \mathrm{~h}$. Afterward, the material was ground in a hammer 
mill (Glen Creston, Ltd., London, UK) and sieved (U.S. ASTM) to obtain fractions of the biosorbent, each with a particular particle size between 0.3 and $2.0 \mathrm{~mm}(0.3-0.5,0.5-0.8,0.8-1.4$, and $1.4-2.0 \mathrm{~mm})$. The fractions were all pretreated with $\mathrm{K}_{2} \mathrm{HPO}_{4}$. Briefly, $5 \mathrm{~g}$ (dry weight) of Lemna gibba per liter were exposed to $\mathrm{K}_{2} \mathrm{HPO}_{4}(0.3 \mathrm{M})$ at $18{ }^{\circ} \mathrm{C}$ for $30 \mathrm{~min}$. During the pretreatment, the material was agitated at $140 \mathrm{rpm}$ in an orbital shaker (All Sheng ${ }^{\mathrm{TM}}$, Hangzhou Allsheng Instruments Co, Ltd., Hangzhou, China). Upon completion of the exposure time, the biosorbent was washed with deionized water. When the resulting wash water had a $\mathrm{pH}$ near the deionized water being used, the material was dried in an oven at $60{ }^{\circ} \mathrm{C}$ for $48 \mathrm{~h}$ [17]. Each fraction of dried, pretreated Lemna gibba (PLEM) was stored in a separate, well-labeled, hermetically-sealed bottle at room temperature (rt).

\subsection{The Influence of Different Physicochemical Parameters on the Biosorption of $\mathrm{Co}^{2+}$ by PLEM}

Experiments to evaluate the effect of several physicochemical variables on the biosorption of $\mathrm{Co}^{2+}$ by PLEM were carried out in $500 \mathrm{~mL}$ Erlenmeyer flasks. They contained $120 \mathrm{~mL}$ of a solution with a known concentration of $\mathrm{Co}^{2+}$ at a predetermined $\mathrm{pH}$ value. Subsequently, an addition was made of $0.12 \mathrm{~g}$ of PLEM at a certain particle size, thus achieving a biosorbent concentration of $1 \mathrm{~g}$ (dry weight) $\mathrm{L}^{-1}$. The suspensions were left at $18{ }^{\circ} \mathrm{C}$ (rt) for $2 \mathrm{~h}$ under constant agitation at $140 \mathrm{rpm}$ in an orbital shaker (All Sheng ${ }^{\mathrm{TM}}$, Hangzhou Allsheng Instruments Co, Ltd., Hangzhou, China). The pH of the solutions was adjusted to the desired value and maintained constant throughout the assay by adding $0.1 \mathrm{M} \mathrm{HCl}$ and $0.01 \mathrm{M} \mathrm{NaOH}$.

Firstly, the $\mathrm{pH}$ varied $(2,3,4,5,6$, and 7$)$, while maintaining the initial concentration of $\mathrm{Co}^{2+}$ $\left(C_{\text {ini }}\right)$ at $100 \mathrm{mg} \mathrm{L}^{-1}$ and the particle size of PLEM at $0.3-0.5 \mathrm{~mm}$. Later, distinct particle sizes (0.3-0.5, $0.5-0.8,0.8-1.4,1.4-2.0$, and $0.3-0.8 \mathrm{~mm}$ ) were utilized, while maintaining $C_{\text {ini }}$ at $100 \mathrm{mg} \mathrm{L}^{-1}$ and the pH at 7.0. Finally, different initial values of $C_{\text {ini }}\left(10,20,40,60,80,100,200\right.$, and $\left.300 \mathrm{mg} \mathrm{L}^{-1}\right)$ were used, while maintaining the $\mathrm{pH}$ at 7.0 and the particle size at $0.3-0.8 \mathrm{~mm}$.

During the experiment, samples were taken at various exposure times and filtered to afford a solution free of biosorbent. The filtrate of each flask was diluted properly for the posterior quantification of the cobalt concentration. From the values obtained, the biosorption capacity of $\mathrm{Co}^{2+}$ by PLEM was calculated at a series of exposure times using Equation (1):

$$
q=\frac{V}{M}\left(C_{i n i}-C\right)
$$

where $q\left(\mathrm{mg} \mathrm{g}^{-1}\right)$ is the capacity of biosorption of $\mathrm{Co}^{2+}, V(\mathrm{~L})$ is the total volume of the solution, $M(\mathrm{~g})$ is the biosorbent mass, and $C_{i n i}$ and $C\left(\mathrm{mg} \mathrm{L}^{-1}\right)$ correspond to the initial concentration of $\mathrm{Co}^{2+}$ in the solution and its concentration at time $t(\mathrm{~h})$, respectively. When the system reaches equilibrium, $t=t_{\text {eq }}$, $C=C_{e q}$ and $q=q_{e q}$. Based on the values of biosorption capacity found, the most suitable $\mathrm{pH}$ of the solution and the best particle size for the removal of $\mathrm{Co}^{2+}$ were selected for the rest of the biosorption experiments. For each of the parameters examined, controls free of biosorbent were established and analyzed for possible changes in the concentration of cobalt.

\subsection{Kinetic Modeling of the Biosorption of $\mathrm{Co}^{2+}$ by PLEM}

For the kinetic modeling of the biosorption of $\mathrm{Co}^{2+}$ by PLEM, the equations of pseudo-first-order, pseudo-second-order, and fractional power were employed (Table 1). 
Table 1. Biosorption models were tested.

\begin{tabular}{|c|c|c|}
\hline Kinetic Models & Equation & Parameters \\
\hline Pseudo-first-order [18] & $q=q_{e q 1}\left[1-e^{\left(-k_{1} t\right)}\right]$ & $\begin{array}{l}k_{1} \text {-pseudo-first-order sorption velocity } \\
\text { constant }\left(\mathrm{min}^{-1}\right) \\
q_{\text {eq } 1 \text { - equilibrium biosorption capacity }} \\
\text { predicted by the model }\left(\mathrm{mg} \mathrm{g}^{-1}\right)\end{array}$ \\
\hline Pseudo-second-order [18] & $q=\frac{t}{\left(\frac{1}{k_{2} * q_{e q 2}{ }^{2}}\right)+\left(\frac{t}{q_{e q}}\right)}$ & $\begin{array}{l}k_{2} \text {-pseudo-second-order sorption velocity } \\
\text { constant }\left(\mathrm{g} \mathrm{mg}^{-1} \mathrm{~min}^{-1}\right) \\
q_{\text {eq } 2 \text {-equilibrium biosorption capacity }} \\
\text { predicted by the model }\left(\mathrm{mg} \mathrm{g}^{-1}\right)\end{array}$ \\
\hline Fractional power [18] & $q=k_{F P} t^{v}$ & $\begin{array}{l}k_{F P} \text { - constant of the model }\left(\mathrm{mg} \mathrm{g}^{-1}\right) \\
v-\text { velocity constant }\left(\mathrm{h}^{-1}\right)\end{array}$ \\
\hline Isothermal models & Equation & Parameters \\
\hline Langmuir $[19,20]$ & $\begin{aligned} q_{e q} & =\frac{q_{m L} b_{L} C_{e q}}{1+b_{L} C_{e q}} \\
R_{L} & =\frac{1}{1+b_{L} C_{i n i}}\end{aligned}$ & $\begin{array}{l}q_{m L} \text {-maximum biosorption capacity } \\
\text { determined by Langmuir }\left(\mathrm{mg} \mathrm{g}^{-1}\right) \\
b_{L} \text { - Langmuir constant, linked to affinity } \\
\text { for the active sites }\left(\mathrm{L} \mathrm{mg}^{-1}\right) \\
C_{i n i} \text {-initial concentration }\left(\mathrm{mg} \mathrm{L}^{-1}\right) \\
R_{L} \text { - separation factor }\end{array}$ \\
\hline Freundlich [19] & $q_{e q}=k_{F} C_{e q}^{1 / n F}$ & $\begin{array}{l}k_{F} \text { - Freundlich constant, related to the } \\
\text { biosorption capacity }\left(\mathrm{mg} \mathrm{g}^{-1}\left(\mathrm{mg} \mathrm{L}^{-1}\right)^{-1 / \mathrm{nF}}\right) \\
n_{F}-\text { Freundlich constant, linked to the } \\
\text { intensity of sorption }\end{array}$ \\
\hline Sips [19] & $q_{e q}=\frac{q_{m S P} k_{S P} C_{e q}{ }^{n} S P}{1+k_{S P} C_{e q}{ }^{n} S P}$ & $\begin{array}{l}q_{m S P} \text { - maximum biosorption capacity, } \\
\text { determined by Sips }\left(\mathrm{mg} \mathrm{g}^{-1}\right) \\
k_{S P} \text {-constant of the model }\left(\mathrm{mg} \mathrm{L}^{-1}\right)^{-\mathrm{nSP}} \\
n_{S P} \text {-exponent of the model }\end{array}$ \\
\hline Redlich-Peterson [19] & $q_{e q}=\frac{k_{R P} C_{e q}}{1+a_{R P} C_{e q} b_{R P}}$ & $\begin{array}{l}k_{R P}-\text { constant of the model }\left(\mathrm{L} \mathrm{g}^{-1}\right) \\
a_{R P}-\text { constant of the model }\left(\mathrm{mg} \mathrm{L}^{-1}\right)^{-\mathrm{bRP}} \\
b_{R P}-\text { exponent of the model }\end{array}$ \\
\hline
\end{tabular}

\subsection{Biosorption Isotherm Studies at Different Temperatures}

In $125 \mathrm{~mL}$ flasks were poured $30 \mathrm{~mL}$ of solutions of $\mathrm{Co}^{2+}$ at distinct concentrations $(20,40,60,80$, 100,200 , and $300 \mathrm{mg} \mathrm{L}^{-1}$ ), adjusting the $\mathrm{pH}$ to 7.0 . Then $0.03 \mathrm{~g}$ of PLEM (particle size $=0.3-0.8 \mathrm{~mm}$ ) was placed in each flask to ensure a concentration of $1 \mathrm{~g} \mathrm{~L}^{-1}$ of PLEM. The suspensions were left for $2 \mathrm{~h}$ at $18,30,40,50$, or $60^{\circ} \mathrm{C}$ to reach biosorption equilibrium. Subsequently, the samples from each flask were filtered, and the residual concentration of $\mathrm{Co}^{2+}$ was quantified in each filtrate. With the experimental results of the biosorption capacity found at equilibrium $\left(q_{e q}\right)$ and the residual concentration of cobalt at equilibrium $\left(C_{e q}\right)$ for each initial concentration of metal assayed $\left(C_{i n i}\right)$, the isotherm for adsorption was calculated. It was then possible to select the best mathematical model for describing the experimental behavior. With this objective in mind, models of two (Langmuir and Freundlich) and three parameters (Sips and Redlich-Peterson) were used (Table 1).

\subsection{Determination of the Thermodynamic Parameters}

The thermodynamic parameters examined were the changes in Gibbs free energy $\left(\Delta G^{0}, \mathrm{~J} \mathrm{~mol}^{-1}\right)$, in standard entropy $\left(\Delta S^{0}, \mathrm{~J} \mathrm{~mol}^{-1} \mathrm{~K}^{-1}\right)$, and in standard enthalpy $\left(\Delta H^{0}, \mathrm{~J} \mathrm{~mol}^{-1}\right)$. With the data on the isotherms for biosorption at equilibrium, the coefficient of distribution $\left(K_{d}, \mathrm{~L} \mathrm{~g}^{-1}\right)$ was obtained for each temperature and concentration assayed using Equation (2) [21]:

$$
K_{d}=\frac{q_{e q}}{C_{e q}}
$$


In the graph of Ln $K_{d}$ vs. $C_{e q}$ for each temperature, the point at which the ordinate crosses the origin corresponds to $\operatorname{Ln} K_{0}\left(K_{0}\right.$ being the sorption constant at equilibrium, $\left.\mathrm{L} \mathrm{g}^{-1}\right)$. These values were substituted in Equation (3) to find the change in Gibbs free energy [22]:

$$
\Delta G^{0}=-R T \operatorname{Ln} K_{0}
$$

where $R$ is the constant of the ideal gases $\left(8.315 \mathrm{~J} \mathrm{~mol}^{-1} \mathrm{~K}^{-1}\right)$, and $T$ is the absolute temperature $(\mathrm{K})$ during biosorption. The change in standard entropy $\left(\Delta S^{0}\right)$ was found by Equation (4):

$$
\Delta S^{0}=\frac{\partial \Delta G^{0}}{\partial T}
$$

The slope of the graph of $\Delta G^{0}$ vs. $T$ indicates the mean value of $\Delta S^{0}$. The change in the standard enthalpy was furnished by Equation (5):

$$
\Delta G^{0}=\Delta H^{0}+T \Delta S^{0}
$$

\subsection{Desorption of $\mathrm{Co}^{2+}$ from the Biosorbent}

To evaluate desorption, the biosorbent was first saturated by exposing PLEM $\left(1 \mathrm{~g} \mathrm{~L}^{-1}\right.$, with a particle size of $0.3-0.8 \mathrm{~mm})$ to a solution of $\mathrm{Co}^{2+}\left(300 \mathrm{mg} \mathrm{L}^{-1}, \mathrm{pH} 7.0, \mathrm{rt}\right)$ under constant agitation at $140 \mathrm{rpm}$ for $2 \mathrm{~h}$. Upon completion of this time, the biosorbent was washed with deionized water several times to eliminate the excess cobalt and then dried in an oven at $60{ }^{\circ} \mathrm{C}$ for $48 \mathrm{~h}$. Finally, it was stored in hermetically-sealed bottles until further use.

For the desorption of $\mathrm{Co}^{2+}$ from PLEM, diverse solutions were tested as eluents: Water at $\mathrm{rt}$ $\left(\mathrm{H}_{2} \mathrm{O} \mathrm{rt}\right.$, the control), water at $60{ }^{\circ} \mathrm{C}\left(\mathrm{H}_{2} \mathrm{O} 60{ }^{\circ} \mathrm{C}\right)$, various acidic solutions $\left(\mathrm{HCl}, \mathrm{H}_{2} \mathrm{SO}_{4}, \mathrm{HNO}_{3}\right.$, $\mathrm{C}_{2} \mathrm{H}_{2} \mathrm{O}_{4}, \mathrm{KH}_{2} \mathrm{PO}_{4}$, and $\left.\mathrm{NH}_{4} \mathrm{Cl}\right)$ and three alkaline compounds $\left(\mathrm{NaOH}, \mathrm{NaHCO}\right.$, and $\left.\mathrm{K}_{2} \mathrm{HPO}_{4}\right)$. The concentration of all compounds was $0.1 \mathrm{M}$. Desorption was carried out by placing $120 \mathrm{~mL}$ of one of the distinct eluent solutions in each Erlenmeyer flask and adding the saturated biosorbent at a concentration of $1 \mathrm{~g} \mathrm{~L}^{-1}$. The material was maintained under constant agitation at $140 \mathrm{rpm}$ and $18{ }^{\circ} \mathrm{C}$ for $2 \mathrm{~h}$, collecting and filtering samples from each of the flasks at different times. The concentration of desorbed metal on each filtrate was quantified. The percentage of desorption at time $t$ was calculated with Equation (6) [23]:

$$
E_{D}(\%)=\frac{V\left(C_{D}-C_{i n i}\right)}{M q_{e q}} \times 100
$$

where $C_{i n i}$ and $C_{D}\left(\mathrm{mg} \mathrm{L}^{-1}\right)$ are the initial concentration of metal in the solution $(t=0 \mathrm{~h})$ and the concentration of $\mathrm{Co}^{2+}$ eluted from the solution at time $t$, respectively, and $q_{e q}\left(\mathrm{mg} \mathrm{g}^{-1}\right)$ is the amount of $\mathrm{Co}^{2+}$ retained per gram of biosorbent (determined experimentally). The results of the percentage of the desorption were compared to select the adequate solution for eluting $\mathrm{Co}^{2+}$ from PLEM.

\subsection{Biosorption-Desorption Cycles}

PLEM was saturated with $\mathrm{Co}^{2+}$ for $2 \mathrm{~h}$, as described in the previous section. Upon completion of this time, samples of the solution were taken to assess the biosorption capacity of PLEM in the first stage (Equation (1)). Subsequently, the saturated biosorbent was washed, dried, and subjected to the desorption of $\mathrm{Co}^{2+}$ (as already explained) by putting $1 \mathrm{~g} \mathrm{~L}^{-1}$ of the material in a solution with the selected eluent and leaving it under constant agitation at $140 \mathrm{rpm}$ and $\mathrm{rt}$ for $2 \mathrm{~h}$. Samples were then taken to quantify the concentration of $\mathrm{Co}^{2+}$ in the solution and calculate the percentage of desorption for the first cycle (Equation (6)). PLEM was washed with deionized water and dried at $60{ }^{\circ} \mathrm{C}$ for $48 \mathrm{~h}$ to be submitted to posterior cycles. Three cycles of biosorption/desorption were carried out under the same conditions, allowing for the comparison of the capacity of biosorption and percentage of desorption from one cycle to another. 


\subsection{Scanning Electron Microscope Coupled to Energy-Dispersive X-ray Spectroscopy (SEM-EDX)}

The possible changes in the structure and composition of the surface of PLEM, due to the process of biosorption and the posterior desorption of $\mathrm{Co}^{2+}$ were explored on a scanning electron microscope (SEM). The three types of samples of PLEM (unexposed to $\mathrm{Co}^{2+}$, saturated, and desorbed in the first cycle) were dried for $24 \mathrm{~h}$ at $60^{\circ} \mathrm{C}$. Subsequently, they were covered with carbon to be later observed with a JEOL high-resolution scanning electron microscopy (HR-SEM) (model JSM7800F, Jeol Ltd., Tokyo, Japan) with an acceleration voltage of $5 \mathrm{kV}$.

\subsection{Analytical Methods}

$\mathrm{Co}^{2+}$ was quantified by the dimethylglyoxime (DMG) method, with which a compound is formed with an intensity of color proportional to the concentration of $\mathrm{Co}^{2+}$ present in the solution [24]. The measurement of absorbance was conducted in a Spectronic Genesys UV/Vis 10 spectrophotometer (Thermo Electron Scientific Instruments Corp, Madison, WI, USA) at $400 \mathrm{~nm}$. The concentration of $\mathrm{Co}^{2+}$ was established by constructing metal-type curves with at least 10 distinct known concentrations.

\subsection{Statistical Analysis}

Each experiment was performed independently at least twice, and the determinations of residual cobalt were made at least three times, with the aim of attaining the appropriate statistical power. Data are expressed as the mean \pm standard deviation (SD) of the values obtained experimentally. Regarding the values from the kinetics of biosorption and the experimental biosorption capacity at equilibrium $\left(q_{e q}\right)$, differences between groups were examined with two-way ANOVA and Tukey's test (with a confidence interval of $\alpha=0.05$ ) on the GraphPad Prism ${ }^{\circledR}$ Ver 8.4 program 2020 (GraphPad Software Inc, San Diego, CA, USA). The kinetic and equilibrium parameters were scrutinized by nonlinear regression on the same software, selecting the best model in accordance with a variety of error functions: The correlation coefficient $\left(R^{2}\right)$, the absolute sum of squares $(A S E)$, the standard deviation of the residuals $(S y . x)$ and Akaike's information criterion $(A I C c)$. The data from the three cycles of biosorption/desorption were compared with one-way ANOVA and Dunnett's test (confidence interval, $\alpha=0.05$ ) on the GraphPad Prism ${ }^{\circledR}$ Ver 8.4 program 2020 (GraphPad Software Inc., San Diego, CA, USA).

\section{Results and Discussion}

No change in the concentration of $\mathrm{Co}^{2+}$ was found for the PLEM-free solutions, used as controls for the evaluation of the influence of the physicochemical conditions herein tested. Thus, the removal of $\mathrm{Co}^{2+}$ from the aqueous solution can be fully attributed to the effect of biosorption produced by PLEM.

\subsection{The Effect of $p H$}

The level of $\mathrm{pH}$ is one of the physicochemical factors that most influence the biosorption of heavy metals [25]. The $\mathrm{pH}$ values of 2-7 were presently employed because the precipitation of cobalt was observed experimentally as of $\mathrm{pH} 8$, likely due to the formation of cobalt hydroxide [26,27]. At each $\mathrm{pH}$ value, the biosorption capacity was evaluated with respect to time (Figure 1a). With the $\mathrm{pH}$ at 2 or 3 , the cobalt removal capacity was near 0 . 

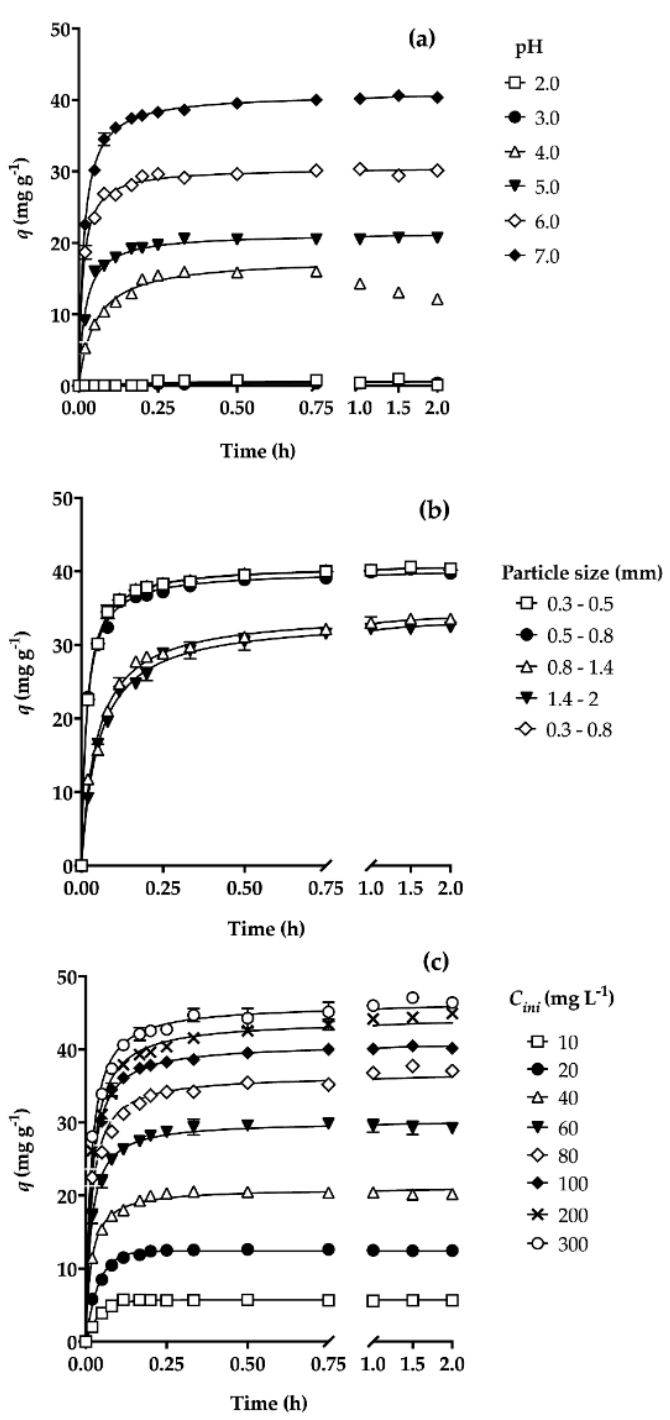

Figure 1. Capacity of biosorption of $\mathrm{Co}^{2+}$ by pretreated Lemna gibba (PLEM): (a) At various $\mathrm{pH}$ values of the solution $\left(C_{i n i}=100 \mathrm{mg} \mathrm{L}^{-1}\right.$, particle size $\left.=0.3-0.5 \mathrm{~mm}\right)$, (b) with distinct particle sizes of $\operatorname{PLEM}\left(C_{i n i}=100 \mathrm{mg} \mathrm{L}^{-1}, \mathrm{pH}=7.0\right)$, and $(\mathbf{c})$ at different initial concentrations of the metal $(\mathrm{pH}=7.0$, particle size $=0.3-0.8 \mathrm{~mm})$. The continuous lines were predicted by the pseudo-second-order kinetic model.

The sorption capacity was enhanced with each increment in $\mathrm{pH}$ from 4 to 7 , which can be easily explained by considering the $\mathrm{pH}$ of the plant material (1.67), which results in zero point of charge $\left(\zeta_{0}\right)$ [17]. When the $\mathrm{pH}$ of a solution is less than that found at $\zeta_{0}$, the net charge of the surface of the biosorbent is positive. Hence, an electrostatic repulsion exists between the positive charge of both the metal ions and the surface of the biosorbent [28]. In contrast, when a solution has a $\mathrm{pH}$ value above that at $\zeta_{0}$, the net charge of the surface of the biosorbent is negative, and there is an attraction with the positively charged metal ion [29]. A pH value of 5-7 herein afforded the fastest biosorption of $\mathrm{Co}^{2+}$ during the first $10 \mathrm{~min}(0.17 \mathrm{~h})$ of the experiment. After this time, however, the velocity of removal of the metal decreased until reaching equilibrium, at which point the velocity of net transfer was 0 . The initial rapid biosorption was due to the greater number of sites on PLEM available for the uptake of the sorbate and the higher concentration of $\mathrm{Co}^{2+}$ in the aqueous solution. As time passed, the available sites and the concentration of free cobalt ions were both diminished, leading to a gradual decline in the velocity of the removal of $\mathrm{Co}^{2+}$ until reaching the equilibrium dynamic. It was observed that as the $\mathrm{pH}$ increased, the biosorbent removed more $\mathrm{Co}^{2+}$, and therefore, required more time to reach equilibrium 
$\left(t_{e q}\right)$. The same phenomenon has been reported for the effect of $\mathrm{pH}$ on the biosorption of other divalent metal ions [29].

A summary of the of $\mathrm{Co}^{2+}$ removal capacity at experimental equilibrium $\left(q_{e q}\right)$, the time to reach equilibrium $\left(t_{e q}\right)$, and the values of the parameters and error functions for each model and at each $\mathrm{pH}$ value assayed are provided in Table 2 . None of the kinetic models employed fit the experimental results at $\mathrm{pH} 2$ or 3, probably owing to the minimal biosorption of $\mathrm{Co}^{2+}$ under these conditions. At $\mathrm{pH} 4$, a reduction in the removal capacity was only found after $0.75 \mathrm{~h}$ (Figure 1a), a time period not included in the process of biosorption. Hence, the corresponding data was not considered when determining the values of the parameters for the kinetic models. With a $\mathrm{pH}$ of 4-7, the pseudo-second-order model had the highest correlation coefficient $\left(R^{2}\right)$ and the lowest values for ASE, Sy.x, and AICC compared to the other two models (pseudo-first-order and fractional power). The Elovich model was also evaluated, but is not listed in the tables because the $R^{2}$ was too small, and the parameters obtained had exaggerated $S D$ values. Given that a $\mathrm{pH}$ of 7 produced the greatest biosorption capacity at equilibrium, this value was used for further testing.

Table 2. Kinetic parameters of the biosorption of $\mathrm{Co}^{2+}$ by $P L E M$ at various $\mathrm{pH}$ values of the solution $\left(C_{\text {ini }}=100 \mathrm{mg} \mathrm{L}^{-1}\right.$, particle size $\left.=0.3-0.5 \mathrm{~mm}\right)$.

\begin{tabular}{|c|c|c|c|c|}
\hline \multirow{2}{*}{ Parameter } & \multicolumn{4}{|c|}{$\mathrm{pH}$} \\
\hline & 4.0 & 5.0 & 6.0 & 7.0 \\
\hline$q_{e q}\left(\mathrm{mg} \mathrm{g}^{-1}\right)$ & $12.35 \pm 0.09$ & $17.85 \pm 0.08$ & $29.78 \pm 0.18$ & $40.13 \pm 0.18$ \\
\hline$t_{e q}(\mathrm{~h})$ & 0.25 & 0.25 & 0.25 & 0.5 \\
\hline \multicolumn{5}{|c|}{ Pseudo-first-order } \\
\hline$q_{e q 1}\left(\mathrm{mg} \mathrm{g}^{-1}\right)$ & $12.19 \pm 0.15$ & $17.51 \pm 0.13$ & $29.20 \pm 0.22$ & $38.80 \pm 0.26$ \\
\hline$k_{1}\left(\mathrm{~h}^{-1}\right)$ & $18.81 \pm 0.98$ & $25.03 \pm 1.11$ & $41.79 \pm 2.32$ & $34.96 \pm 1.59$ \\
\hline$R^{2}$ & 0.9740 & 0.9757 & 0.9699 & 0.9777 \\
\hline$A S E$ & 17.570 & 33.360 & 104.200 & 139.400 \\
\hline Sy.x & 0.6468 & 0.7860 & 1.389 & 1.607 \\
\hline$A I C c$ & -33.79 & -22.54 & 41.25 & 57.55 \\
\hline \multicolumn{5}{|c|}{ Pseudo-second-order } \\
\hline$q_{\text {eq } 2}\left(\mathrm{mg} \mathrm{g}^{-1}\right)$ & $13.69 \pm 0.22$ & $18.61 \pm 0.11$ & $30.57 \pm 0.16$ & $40.86 \pm 0.09$ \\
\hline$k_{2}\left(\mathrm{~g} \mathrm{mg}^{-1} \mathrm{~h}^{-1}\right)$ & $1.88 \pm 0.17$ & $2.28 \pm 0.10$ & $2.51 \pm 0.13$ & $1.50 \pm 0.03$ \\
\hline$R^{2}$ & 0.975 & 0.990 & 0.989 & 0.998 \\
\hline$A S E$ & 16.81 & 13.75 & 35.23 & 12.31 \\
\hline Sy.x & 0.6327 & 0.5046 & 0.8077 & 0.4775 \\
\hline$A I C c$ & -35.73 & -72.18 & -19.50 & -78.37 \\
\hline \multicolumn{5}{|c|}{ Fractional power } \\
\hline$k_{F P}\left(\mathrm{mg} \mathrm{g}^{-1}\right)$ & $15.03 \pm 0.56$ & $18.37 \pm 0.33$ & $30.61 \pm 0.39$ & $40.85 \pm 0.52$ \\
\hline$v\left(\mathrm{~h}^{-1}\right)$ & $0.211 \pm 0.02$ & $0.107 \pm 0.01$ & $0.073 \pm 0.007$ & $0.086 \pm 0.008$ \\
\hline$R^{2}$ & 0.758 & 0.676 & 0.667 & 0.7293 \\
\hline$A S E$ & 68.31 & 133.90 & 190.00 & 342.90 \\
\hline Sy.x & 1.341 & 1.637 & 1.949 & 2.619 \\
\hline$A I C c$ & 55.70 & 80.49 & 73.88 & 104.6 \\
\hline
\end{tabular}




\subsection{The Effect of Particle Size}

Particle size is a physical property that affects the surface area of contact between a sorbent and the liquid phase, thus playing a key role in biosorption $[30,31]$. When the particle size is reduced, the area of contact is amplified, and the sites of sorption are more accessible, generating a better capacity, efficiency, and velocity of biosorption and a decrease in the time to reach equilibrium (Figure 1b). The present results are in agreement with previous reports of an enhanced biosorption capacity as the particle size diminishes, considering particles from 0.3 to $2.0 \mathrm{~mm}$ (Table 3).

Table 3. Kinetic parameters of the biosorption of $\mathrm{Co}^{2+}$ by PLEM, using different particle sizes $\left(C_{\text {ini }}=100 \mathrm{mg} \mathrm{L}^{-1}, \mathrm{pH}=7.0\right)$.

\begin{tabular}{|c|c|c|c|c|c|}
\hline \multirow{2}{*}{ Parameter } & \multicolumn{5}{|c|}{ Particle Size (mm) } \\
\hline & $0.3-0.5$ & $0.5-0.8$ & $0.8-1.4$ & $1.4-2$ & $0.3-0.8$ \\
\hline$q_{e q}\left(\mathrm{mg} \mathrm{g}^{-1}\right)$ & $40.13 \pm 0.18$ & $39.77 \pm 0.25$ & $33.38 \pm 0.17$ & $32.25 \pm 0.07$ & $40.05 \pm 0.16$ \\
\hline$t_{e q}(\mathrm{~h})$ & 0.5 & 0.75 & 1.0 & 1.0 & 0.5 \\
\hline \multicolumn{6}{|c|}{ Pseudo-first-order } \\
\hline$q_{e q 1}\left(\mathrm{mg} \mathrm{g}^{-1}\right)$ & $38.80 \pm 0.26$ & $38.01 \pm 0.29$ & $31.74 \pm 0.32$ & $30.91 \pm 0.31$ & $38.76 \pm 0.25$ \\
\hline$k_{1}\left(\mathrm{~h}^{-1}\right)$ & $34.96 \pm 1.59$ & $36.02 \pm 1.98$ & $13.66 \pm 0.62$ & $12.41 \pm 0.52$ & $35.08 \pm 1.56$ \\
\hline$R^{2}$ & 0.978 & 0.968 & 0.969 & 0.973 & 0.979 \\
\hline$A S E$ & 139.4 & 191.9 & 154.2 & 130.8 & 134.0 \\
\hline Sy.x & 1.607 & 1.885 & 1.690 & 1.556 & 1.575 \\
\hline$A I C c$ & 57.55 & 75.43 & 63.20 & 53.97 & 55.32 \\
\hline \multicolumn{6}{|c|}{ Pseudo-second-order } \\
\hline$q_{e q 2}\left(\mathrm{mg} \mathrm{g}^{-1}\right)$ & $40.86 \pm 0.09$ & $40.07 \pm 0.10$ & $34.45 \pm 0.23$ & $33.64 \pm 0.19$ & $40.80 \pm 0.09$ \\
\hline$k_{2}\left(\mathrm{~g} \mathrm{mg}^{-1} \mathrm{~h}^{-1}\right)$ & $1.50 \pm 0.03$ & $1.55 \pm 0.04$ & $0.61 \pm 0.02$ & $0.56 \pm 0.02$ & $1.52 \pm 0.09$ \\
\hline$R^{2}$ & 0.998 & 0.998 & 0.991 & 0.994 & 0.998 \\
\hline$A S E$ & 12.31 & 14.66 & 46.04 & 27.98 & 11.73 \\
\hline Sy.x & 0.478 & 0.521 & 0.923 & 0.720 & 0.466 \\
\hline$A I C c$ & -78.37 & -68.58 & -4.504 & -32.39 & -81.09 \\
\hline \multicolumn{6}{|c|}{ Fractional power } \\
\hline$k_{F P}\left(\mathrm{mg} \mathrm{g}^{-1}\right)$ & $40.85 \pm 0.52$ & $40.18 \pm 0.45$ & $33.06 \pm 0.58$ & $32.02 \pm 0.59$ & $40.78 \pm 0.52$ \\
\hline$v\left(\mathrm{~h}^{-1}\right)$ & $0.09 \pm 0.01$ & $0.09 \pm 0.01$ & $0.17 \pm 0.01$ & $0.18 \pm 0.01$ & $0.08 \pm 0.01$ \\
\hline$R^{2}$ & 0.729 & 0.781 & 0.819 & 0.814 & 0.723 \\
\hline$A S E$ & 342.9 & 256.4 & 422.2 & 453.9 & 348.1 \\
\hline Sy.x & 2.619 & 2.265 & 2.906 & 3.013 & 2.638 \\
\hline AICc & 104.6 & 89.47 & 115.4 & 119.2 & 105.4 \\
\hline
\end{tabular}

The biosorption of $\mathrm{Co}^{2+}$ was not significantly different $(p>0.05)$ between the size intervals of $0.3-0.5 \mathrm{~mm}$ and $0.5-0.8 \mathrm{~mm}$. Therefore, a kinetic study was carried out to remove $\mathrm{Co}^{2+}$ by PLEM at a particle size of $0.3-0.8 \mathrm{~mm}$. The statistical analysis with two-way ANOVA and Tukey's test indicated the lack of significant difference $(p>0.05)$ between the equilibrium biosorption capacity $q_{e q}$ values of the samples with the following three particle sizes: $0.3-0.5,0.5-0.8 \mathrm{~mm}$, and $0.3-0.8 \mathrm{~mm}$. The $\mathrm{Co}^{2+}$ biosorption rate was slightly faster (as expected) at the smaller particle size range $(0.3-0.5 \mathrm{~mm})$, reaching equilibrium at $0.5 \mathrm{~h}$. The particle size range of $0.5-0.8 \mathrm{~mm}$ achieved equilibrium in a longer period of time $(0.75 \mathrm{~h})$, probably due to the greater surface area available with a smaller particle size, leading to faster binding of $\mathrm{Co}^{2+}$ ions to the surface of the biosorbent. With a particle size range of $0.3-0.8 \mathrm{~mm}$, the time required to reach equilibrium $\left(t_{e q}\right)$ of $\mathrm{Co}^{2+}$ biosorption by PLEM was $0.5 \mathrm{~h}$, similar to the time found for the smallest particles tested $(0.3-0.5 \mathrm{~mm})$. 
One advantage of employing a particle size of $0.3-0.8 \mathrm{~mm}$ is that it is possible to utilize fixed-bed columns packed with the material. Volesky [32] suggested using a particle size of $0.4-0.7 \mathrm{~mm}$, since smaller sizes could obstruct the bed and provoke a drop in pressure. Additionally, particles of $0.3-0.8 \mathrm{~mm}$ (but not smaller) allow for the application of more biosorbent material. If the particle size range is under $0.3 \mathrm{~mm}$, pretreatment is more difficult. Hence, a particle size of $0.3-0.8 \mathrm{~mm}$ was chosen for the rest of the experiments. The experimental results of the $\mathrm{Co}^{2+}$ removal capacity at equilibrium $\left(q_{e q}\right)$ were compared to the parameters of the kinetic models assayed (Table 3$)$. As can be appreciated, the equation of the pseudo-second-order model shows a higher correlation coefficient $\left(R^{2}\right)$ and lower error functions ( $A S E, S y \cdot x$, and $A I C C$ ) than the other two models.

\subsection{The Effect of the Initial $\mathrm{Co}^{2+}$ Concentration}

The initial concentration of metallic ions is an important variable because it significantly affects the biosorption capacity and the time to reach equilibrium [33]. A boost in the initial concentration of the metal from 10 to $300 \mathrm{mg} \mathrm{L}^{-1}$ generated an 8.46-fold rise (from 5.46 to $46.17 \mathrm{mg} \mathrm{g}^{-1}$ ) in the biosorption capacity at equilibrium (Figure 1c). Increasing the initial concentration of the sorbate, while maintaining the concentration of the biosorbent constant likely amplified the driving force behind sorption (the transfer of the cobalt ions from the aqueous solution to the surface of the biosorbent), a consequence of the higher gradient of concentration. Moreover, there is a greater probability of $\mathrm{Co}^{2+}$ binding to the active sites available in the sorbent, which would bring about a better biosorption capacity [34]. The experimental data on biosorption capacity at equilibrium $\left(q_{e q}\right)$, the time required to reach equilibrium $\left(t_{e q}\right)$, and the values of the parameters of the kinetic models and their corresponding error functions are listed in Table 4. Of the theoretical models applied to the data, the pseudo-second-order model gave the values closest to those found experimentally (as occurred with the other environmental variables) for the distinct initial concentrations of $\mathrm{Co}^{2+}$.

The sorption velocity $\left(k_{2}\right)$ is a kinetic parameter known to be related to the time to reach equilibrium, and therefore, depends on the initial concentration of the metal. The analysis of the kinetic parameters with two-way ANOVA and multiple comparisons by Tukey's test revealed a significant difference in relation to $t_{e q}$ and $k_{2}$ between two initial concentrations of $\mathrm{Co}^{2+}\left(C_{i n i}\right): 10$ and $300 \mathrm{mg} \mathrm{L}^{-1}$. The corresponding values for $t_{e q}$ were 0.05 and $0.75 \mathrm{~h}$, while those for $k_{2}$ were 6.847 and $1.402 \mathrm{~g} \mathrm{mg}^{-1} \mathrm{~h}^{-1}$, respectively (Table 4). Thus, an increase in the initial concentration of cobalt led to a decrease in $k_{2}$ and a longer time necessary to reach equilibrium, which is in agreement with previous reports on the biosorption of metallic ions $[33,35]$. 
Table 4. Kinetic parameters of the biosorption of $\mathrm{Co}^{2+}$ by $P L E M$ at various initial concentrations of the metal (particle size $\left.=0.3-0.8 \mathrm{~mm}, \mathrm{pH}=7.0\right)$.

\begin{tabular}{|c|c|c|c|c|c|c|c|c|}
\hline \multirow{2}{*}{ Parameter } & \multicolumn{8}{|c|}{$C_{i n i}\left(\mathrm{mg} \mathrm{L}^{-1}\right)$} \\
\hline & 10 & 20 & 40 & 60 & 80 & 100 & 200 & 300 \\
\hline$q_{\text {eq }}\left(\mathrm{mg} \mathrm{g}^{-1}\right)$ & $5.46 \pm 0.16$ & $12.18 \pm 0.20$ & $20.20 \pm 0.13$ & $29.22 \pm 0.19$ & $36.44 \pm 0.48$ & $40.05 \pm 0.16$ & $44.22 \pm 0.31$ & $46.17 \pm 0.41$ \\
\hline$t_{\text {eq }}(\mathrm{h})$ & 0.05 & 0.08 & 0.16 & 0.2 & 0.5 & 0.5 & 0.75 & 0.75 \\
\hline \multicolumn{9}{|c|}{ Pseudo-first-order } \\
\hline$q_{e q 1}\left(\mathrm{mg} \mathrm{g}^{-1}\right)$ & $5.71 \pm 0.03$ & $12.44 \pm 0.07$ & $19.95 \pm 0.14$ & $28.64 \pm 0.23$ & $34.53 \pm 0.41$ & $38.76 \pm 0.25$ & $41.56 \pm 0.46$ & $43.81 \pm 0.42$ \\
\hline$k_{1}\left(\mathrm{~h}^{-1}\right)$ & $24.01 \pm 0.85$ & $25.00 \pm 0.81$ & $32.93 \pm 1.58$ & $34.58 \pm 1.91$ & $35.81 \pm 2.94$ & $35.08 \pm 1.56$ & $33.50 \pm 2.53$ & $37.68 \pm 2.58$ \\
\hline$R^{2}$ & 0.9853 & 0.9871 & 0.9741 & 0.9666 & 0.9288 & 0.9785 & 0.9371 & 0.9514 \\
\hline$A S E$ & 2.324 & 8.894 & 43.08 & 113.9 & 356.2 & 134.0 & 456.9 & 384.9 \\
\hline Sy.x & 0.2075 & 0.4058 & 0.8932 & 1.452 & 2.568 & 1.575 & 2.909 & 2.670 \\
\hline$A I C c$ & -171.7 & -96.58 & -8.221 & 46.20 & 110.1 & 55.32 & 124.0 & 114.4 \\
\hline \multicolumn{9}{|c|}{ Pseudo-second-order } \\
\hline$q_{\text {eq } 2}\left(\mathrm{mg} \mathrm{g}^{-1}\right)$ & $6.05 \pm 0.09$ & $13.15 \pm 0.09$ & $20.97 \pm 0.10$ & $30.13 \pm 0.15$ & $36.52 \pm 0.27$ & $40.80 \pm 0.09$ & $44.03 \pm 0.26$ & $46.19 \pm 0.23$ \\
\hline$k_{2}\left(\mathrm{~g} \mathrm{mg}^{-1} \mathrm{~h}^{-1}\right)$ & $6.85 \pm 0.76$ & $3.37 \pm 0.20$ & $2.85 \pm 0.13$ & $2.06 \pm 0.09$ & $1.65 \pm 0.11$ & $1.52 \pm 0.03$ & $1.27 \pm 0.07$ & $1.40 \pm 0.07$ \\
\hline$R^{2}$ & 0.9456 & 0.9830 & 0.9915 & 0.9915 & 0.9804 & 0.9981 & 0.9882 & 0.9912 \\
\hline$A S E$ & 8.617 & 11.74 & 14.17 & 29.02 & 98.25 & 11.73 & 85.78 & 69.72 \\
\hline Sy.x & 0.3995 & 0.4663 & 0.5122 & 0.7331 & 1.349 & 0.4660 & 1.260 & 1.136 \\
\hline AICc & -98.35 & -81.02 & -70.50 & -30.34 & 37.94 & -81.09 & 30.34 & 18.74 \\
\hline \multicolumn{9}{|c|}{ Fractional power } \\
\hline$k_{F P}\left(\mathrm{mg} \mathrm{g}^{-1}\right)$ & $5.89 \pm 0.16$ & $12.92 \pm 0.26$ & $20.84 \pm 0.32$ & $30.05 \pm 0.42$ & $36.85 \pm 0.36$ & $40.78 \pm 0.53$ & $44.33 \pm 0.41$ & $46.49 \pm 0.46$ \\
\hline$v\left(\mathrm{~h}^{-1}\right)$ & $0.099 \pm 0.02$ & $0.099 \pm 0.01$ & $0.083 \pm 0.009$ & $0.083 \pm 0.008$ & $0.095 \pm 0.005$ & $0.085 \pm 0.007$ & $0.098 \pm 0.005$ & $0.088 \pm 0.006$ \\
\hline $\mathrm{R}^{2}$ & 0.4581 & 0.5935 & 0.6402 & 0.6845 & 0.8463 & 0.7226 & 0.8675 & 0.8184 \\
\hline$A S E$ & 31.46 & 84.08 & 128.5 & 218.8 & 157.8 & 348.1 & 206.0 & 269.9 \\
\hline Sy.x & 0.7932 & 1.297 & 1.603 & 2.092 & 1.777 & 2.638 & 2.030 & 2.323 \\
\hline AICC & -19.63 & 31.48 & 53.53 & 81.21 & 64.23 & 105.4 & 78.08 & 92.13 \\
\hline
\end{tabular}




\subsection{Biosorption Isotherm Studies at Various Temperatures}

To understand the sorbate-sorbent interaction, it is crucial to assess the isotherm of biosorption and model it at several temperatures. This approach also allows for the prediction of the maximum biosorption capacity of the sorbent $\left(q_{m}\right)$ and consequently a comparison of distinct sorbents (a prerequisite for the design of an adsorption system) [36,37]. Biosorption at equilibrium was established by examining the variation of the biosorption capacity at equilibrium $\left(q_{\text {eq }}\right)$ with respect to the concentration of the sorbent at equilibrium $\left(C_{e q}\right)$. The relation between the experimental isotherms and those predicted by the theoretical models for the biosorption of $\mathrm{Co}^{2+}$ by PLEM at different temperatures is shown in Figure 2.
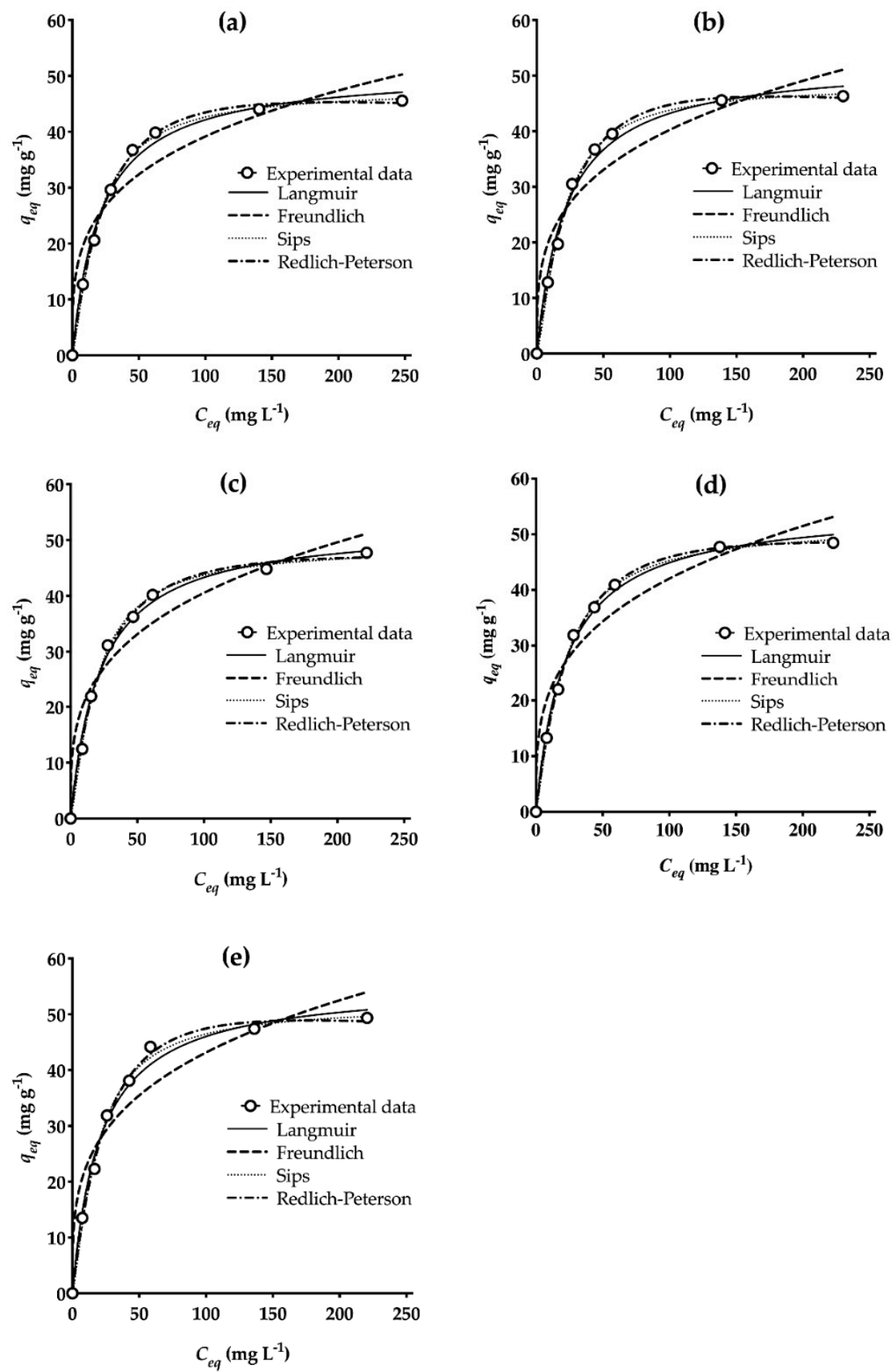

Figure 2. Isotherms for the adsorption of $\mathrm{Co}^{2+}$ by PLEM at the following temperatures: (a) $18^{\circ} \mathrm{C}$, (b) $30{ }^{\circ} \mathrm{C}$, (c) $40{ }^{\circ} \mathrm{C}$, (d) $50{ }^{\circ} \mathrm{C}$, and $(\mathbf{e}) 60^{\circ} \mathrm{C}(\mathrm{pH}=7.0$, particle size $=0.3-0.8 \mathrm{~mm})$. 
The maximum experimental sorption capacity $\left(q_{m} \exp \right)$ was determined at each temperature, as were the values of the other parameters and the error functions $\left(R^{2}, A S E, S y \cdot x\right.$, and $\left.A I C c\right)$ for the models of isotherms (Table 5).

Table 5. Isotherms for the biosorption of $\mathrm{Co}^{2+}$ by PLEM.

\begin{tabular}{|c|c|c|c|c|c|}
\hline \multirow{2}{*}{ Parameter } & \multicolumn{5}{|c|}{ Temperature $\left({ }^{\circ} \mathrm{C}\right)$} \\
\hline & 18 & 30 & 40 & 50 & 60 \\
\hline$q_{m \exp }\left(\mathrm{mg} \mathrm{g}^{-1}\right)$ & $46.17 \pm 0.41$ & $46.33 \pm 0.19$ & $47.73 \pm 0.12$ & $48.49 \pm 0.21$ & $49.35 \pm 0.22$ \\
\hline \multicolumn{6}{|c|}{ Langmuir } \\
\hline$b_{L}\left(\mathrm{~L} \mathrm{mg}^{-1}\right)$ & $0.047 \pm 0.005$ & $0.046 \pm 0.005$ & $0.046 \pm 0.004$ & $0.045 \pm 0.003$ & $0.048 \pm 0.006$ \\
\hline$q_{m L}\left(\mathrm{mg} \mathrm{g}^{-1}\right)$ & $51.12 \pm 1.49$ & $52.66 \pm 1.82$ & $52.78 \pm 1.48$ & $54.97 \pm 1.27$ & $55.57 \pm 1.91$ \\
\hline$R_{L}$ & $0.508-0.068$ & $0.509-0.073$ & $0.508-0.075$ & $0.513-0.076$ & $0.498-0.071$ \\
\hline$R^{2}$ & 0.993 & 0.990 & 0.993 & 0.996 & 0.990 \\
\hline$A S E$ & 13.65 & 19.18 & 12.9 & 8.856 & 21.46 \\
\hline Sy.x & 1.508 & 1.788 & 1.466 & 1.215 & 1.891 \\
\hline$A I C c$ & 16.28 & 18.99 & 15.82 & 12.81 & 19.89 \\
\hline \multicolumn{6}{|c|}{ Freundlich } \\
\hline$k_{F}\left(\mathrm{mg} \mathrm{g}^{-1}\left(\mathrm{~L} \mathrm{~g}^{-1}\right)^{1 / \mathrm{nF}}\right)$ & $11.05 \pm 2.65$ & $10.82 \pm 2.66$ & $10.6 \pm 2.39$ & $10.94 \pm 2.43$ & $11.71 \pm 2.80$ \\
\hline$n_{F}$ & $3.64 \pm 0.70$ & $3.504 \pm 0.67$ & $3.433 \pm 0.59$ & $3.422 \pm 0.58$ & $3.53 \pm 0.67$ \\
\hline$R^{2}$ & 0.924 & 0.922 & 0.938 & 0.939 & 0.926 \\
\hline ASE & 140.7 & 150.4 & 120.7 & 126 & 161 \\
\hline Sy.x & 4.842 & 5.006 & 4.484 & 4.582 & 5.179 \\
\hline AICc & 34.94 & 35.47 & 33.71 & 34.05 & 36.01 \\
\hline \multicolumn{6}{|c|}{ Sips } \\
\hline$k_{S P}\left(\mathrm{~L} \mathrm{~g}^{-1}\right)$ & $0.022 \pm 0.005$ & $0.018 \pm 0.005$ & $0.022 \pm 0.005$ & $0.026 \pm 0.004$ & $0.023 \pm 0.008$ \\
\hline$q_{m S P}\left(\mathrm{mg} \mathrm{g}^{-1}\right)$ & $47.55 \pm 1.026$ & $48.25 \pm 1.065$ & $48.79 \pm 1.122$ & $51.57 \pm 0.975$ & $51.55 \pm 1.677$ \\
\hline$n_{S P}$ & $1.295 \pm 0.086$ & $1.367 \pm 0.095$ & $1.294 \pm 0.092$ & $1.224 \pm 0.066$ & $1.304 \pm 0.131$ \\
\hline$R^{2}$ & 0.998 & 0.998 & 0.998 & 0.999 & 0.996 \\
\hline$A S E$ & 3.713 & 4.38 & 4.055 & 2.504 & 9.674 \\
\hline Sy.x & 0.8617 & 0.936 & 0.900 & 0.7077 & 1.391 \\
\hline$A I C c$ & 15.19 & 16.51 & 15.9 & 12.04 & 22.85 \\
\hline \multicolumn{6}{|c|}{ Redlich-Peterson } \\
\hline$k_{R P}\left(\mathrm{~L} \mathrm{~g}^{-1}\right)$ & $1.822 \pm 0.096$ & $1.789 \pm 0.126$ & $2.006 \pm 0.222$ & $1.964 \pm 0.099$ & $1.996 \pm 0.178$ \\
\hline$a_{R P}\left(\mathrm{~L} \mathrm{mg}^{-1}\right)^{\mathrm{bRP}}$ & $0.017 \pm 0.003$ & $0.014 \pm 0.004$ & $0.023 \pm 0.009$ & $0.019 \pm 0.004$ & $0.015 \pm 0.006$ \\
\hline$b_{R P}$ & $1.142 \pm 0.029$ & $1.171 \pm 0.044$ & $1.095 \pm 0.057$ & $1.116 \pm 0.028$ & $1.162 \pm 0.054$ \\
\hline$R^{2}$ & 0.999 & 0.998 & 0.996 & 0.999 & 0.997 \\
\hline$A S E$ & 2.111 & 4.197 & 7.774 & 1.824 & 7.069 \\
\hline Sy.x & 0.6498 & 0.9162 & 1.247 & 0.604 & 1.189 \\
\hline AICc & 10.68 & 16.17 & 21.1 & 9.507 & 20.34 \\
\hline
\end{tabular}

Regarding the isotherm models of two parameters, the Langmuir model afforded the best correlation coefficient $\left(R^{2}>0.99\right)$ and the smallest error functions. The value of the separation factor $\left(R_{L}\right)$ reflects the nature of biosorption, which is considered unfavorable with $R_{L} \geq 1$, favorable with $0<R_{L}<1$, an irreversible if $R_{L}=0$ [38]. The values of $R_{L}$ calculated presently indicate that biosorption is favorable $\left(0.07<R_{L}<0.5\right)$ at all temperatures assayed.

On the other hand, each of the models of three parameters (Sips and Redlich-Peterson) provided a higher correlation coefficient $\left(R^{2}>0.996\right)$ and lower error functions than the models of two parameters. Overall, the Redlich-Peterson model gave the lowest error functions. The values of maximum biosorption capacity predicted by the isotherm of Sips $\left(q_{m S P}=47.55\right.$ to $\left.51.55 \mathrm{mg} \mathrm{g}^{-1}\right)$ at the five temperatures herein employed were very close to the experimental data $\left(q_{m} \exp =46.17\right.$ to $\left.49.35 \mathrm{mg} \mathrm{g}^{-1}\right)$. Compared to the capacity for the biosorption of $\mathrm{Co}^{2+}$ previously reported for diverse biosorbents, the value found in the current study reveals an excellent capacity for PLEM (Table 6). Thus, it is an attractive biosorbent for the detoxification of water contaminated with $\mathrm{Co}^{2+}$. 
Table 6. Capacity for the biosorption of $\mathrm{Co}^{2+}$ by different materials.

\begin{tabular}{lccc}
\hline Material & Biosorption Capacity $\mathbf{( \mathbf { m g ~ g } ^ { - 1 } )}$ & $\mathbf{p H}$ & Reference \\
\hline Cocos nucifera leaf & 3.69 & 5 & {$[39]$} \\
Spent coffee & 5.37 & 6 & {$[40]$} \\
Rhytidiadelphus squarrosus & 7.38 & 6 & {$[41]$} \\
Natural hemp fibers & 13.58 & $4.5-5$ & {$[26]$} \\
Activated carbon from hazelnut shells & 13.88 & 6 & {$[42]$} \\
Alginate from Callithamnion corymbosum sp. & 18.79 & 4.4 & {$[43]$} \\
Sargassum wightii & 20.63 & 4.5 & {$[44]$} \\
Carbonized lemon peel & 22.00 & 6 & {$[45]$} \\
Watermelon rind & 23.30 & 5 & {$[46]$} \\
Prunus dulcis bio-char & 27.86 & 7 & {$[36]$} \\
Teak leaves & 29.48 & 5 & {$[47]$} \\
MgCl ${ }_{2}$-pretreated Ficus carica leaves & 33.9 & 6 & {$[48]$} \\
Acacia nilotica & 35.45 & 5 & {$[37]$} \\
NaOH-treated lemon peels & 35.71 & 6 & {$[49]$} \\
Almond green hull & 45.50 & $\mathrm{ND}$ & {$[50]$} \\
PLEM & 46.47 & 7 & The present study \\
Corn silk & 82.04 & 6 & {$[25]$} \\
NaOH-pretreated Mangifera indica leaves & 114 & 5 & {$[51]$} \\
\hline
\end{tabular}

ND, no data.

\subsection{Thermodynamic Parameters}

Graphs were constructed to find the thermodynamic parameters, $\Delta G^{0}$ (Figure 3a), $\Delta H^{0}$, and $\Delta S^{0}$ (Figure 3b), and the corresponding values were determined (Table 7).

(a)

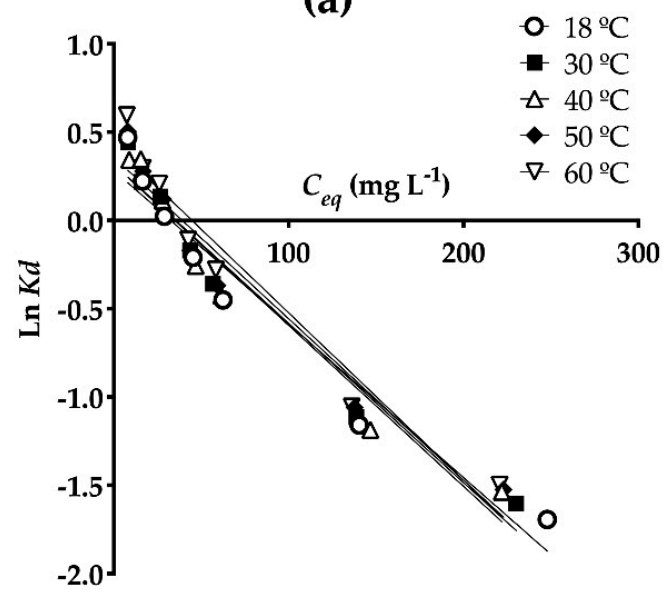

(b)

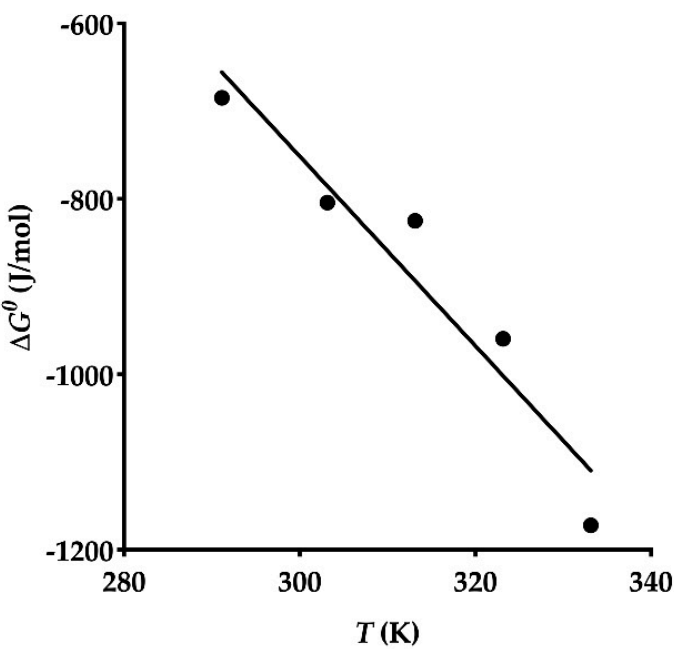

Figure 3. Graphs based on the values of (a) $\operatorname{Ln} K_{d}$ vs. $C_{e q}$ and (b) $\Delta G^{0}$ vs. $T$, which were used to calculate the thermodynamic parameters of biosorption of $\mathrm{Co}^{2+}$ by PLEM.

Table 7. Thermodynamic parameters of biosorption of $\mathrm{Co}^{2+}$ by PLEM.

\begin{tabular}{|c|c|c|c|}
\hline Temperature ${ }^{\circ} \mathrm{C}$ & $\Delta G^{0}\left(\mathrm{~J} \mathrm{~mol}^{-1}\right)$ & $\Delta H^{0}\left(\mathrm{~J} \mathrm{~mol}^{-1}\right)$ & $\Delta S^{0}\left(\mathrm{~J} \mathrm{~mol}^{-1} \mathrm{~K}^{-1}\right)$ \\
\hline 18 & -684.8 & 2461.3 & $10.81 \pm 1.89$ \\
\hline 30 & -804.3 & 2471.6 & \\
\hline 40 & -825.0 & 2558.8 & \\
\hline 50 & -959.4 & 2532.6 & \\
\hline 60 & -1172.1 & 2427.9 & \\
\hline
\end{tabular}

The Gibbs free energy $\left(\Delta G^{0}\right)$ values are negative for the biosorption of $\mathrm{Co}^{2+}$ by PLEM (Table 7), suggesting a spontaneous process. The biosorption has been reported to improve as the temperature 
rises [22]. The positive values of $\Delta H^{0}$ show an endothermic biosorption, which is consistent with the enhanced biosorption capacity $\left(q_{m \text { exp }}\right)$ presently found at higher temperatures (Table 5$)$. The change in the mean calculated standard enthalpy was $\Delta H^{0}$ prom $=2.49 \mathrm{KJ} \mathrm{mol}^{-1}$. A value below $40 \mathrm{~kJ} \mathrm{~mol}^{-1}$ is indicative of a process of physisorption [21]. The positive value of standard entropy $\left(\Delta S^{0}\right)$ reveals a high affinity of $\mathrm{Co}^{2+}$ for PLEM [22], and thus, the probability that the metal promotes structural changes in the biosorbent. Hence, the process of biosorption likely increases the degree of disorder of the whole system $[25,52]$. According to the values of the thermodynamic parameters, adsorption of $\mathrm{Co}^{2+}$ by PLEM is spontaneous and favorable, allowing this material to be utilized for the removal of metal from polluted water.

\subsection{Desorption}

The elution of $\mathrm{Co}^{2+}$ after its sorption by PLEM was tested with various acids and bases (Figure 4). Overall, the strong acids $\left(\mathrm{HCl}, \mathrm{HNO}_{3}\right.$, and $\left.\mathrm{H}_{2} \mathrm{SO}_{4}\right)$ were the best eluent solutions, giving superior desorption percentages $(>94 \%)$ compared to the weak acids $(<65 \%)$ or alkaline compounds $(<20 \%)$. Water, whether at $\mathrm{rt}$ or $60{ }^{\circ} \mathrm{C}$, was not capable of eluting more than $10 \%$ of $\mathrm{Co}^{2+}$.

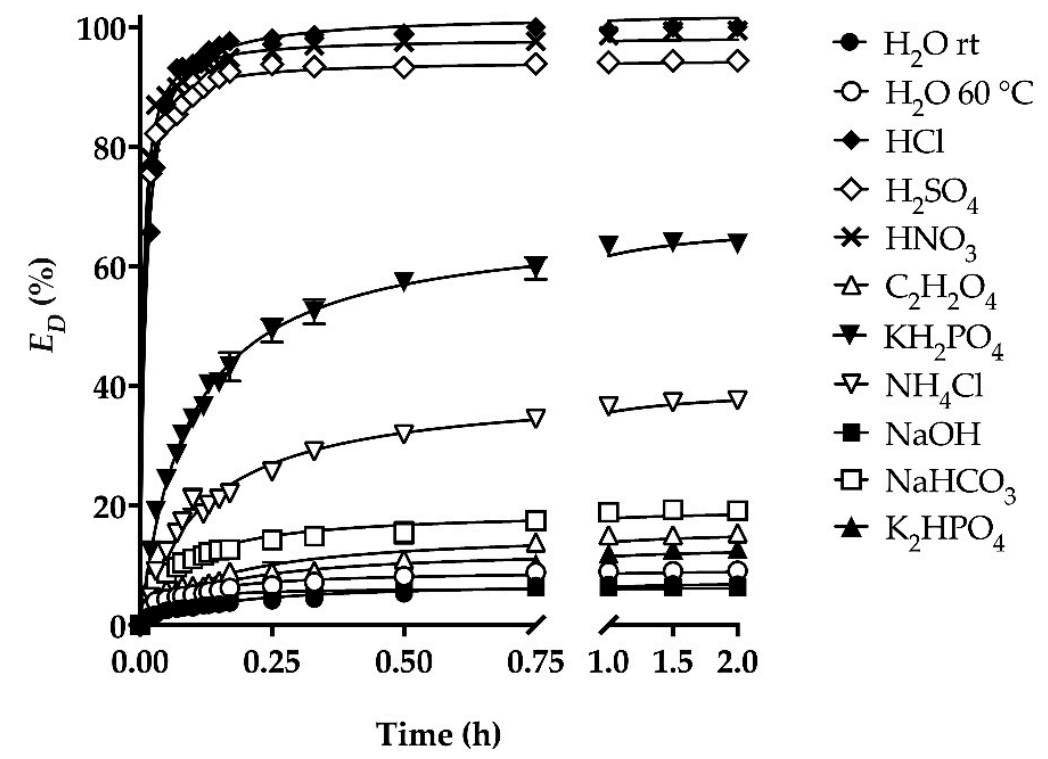

Figure 4. Kinetics of desorption of $\mathrm{Co}^{2+}$ from PLEM with distinct eluent solutions.

Thus, the biosorbent was positively charged at the $\mathrm{pH}$ of acid solutions, resulting in an electrostatic repulsion with the sorbate [53]. Accordingly, physisorption seems to play a key role in the process of biosorption of $\mathrm{Co}^{2+}$ by PLEM. On the other hand, a high concentration of $\mathrm{H}^{+}$ions in the acid solutions could cause competition with $\mathrm{Co}^{2+}$ for these sorption sites, favoring ionic interchange, and consequently, the desorption process [54]. Since $0.1 \mathrm{M} \mathrm{HCl}$ was the eluent with the greatest percentage of desorption $(100 \%)$, the biosorbent was eluted with this solution in posterior assays.

The effect of $\mathrm{pH}$ on the biosorption/desorption of $\mathrm{Co}^{2+}$ suggests that the main biosorption mechanism is electrostatic attraction, a physical process between negatively charged groups of the biosorbent and the positive charge of $\mathrm{Co}^{2+}$. The thermodynamic value of $\Delta H^{0}$ prom $\left(2.49 \mathrm{KJ} \mathrm{mol}^{-1}\right)$ indicates a physisorption process, which reinforces the idea of electrostatic attraction being the principal mechanism of biosorption.

\subsection{Biosorption-Desorption Cycles}

Considering the indispensable requirement of recyclability for the practical application of a biosorbent, an evaluation of the cycles of biosorption/desorption is necessary to assure that the material can be regenerated in a cost-effective manner [23]. Additionally, insights are provided as to the best 
way to dispose of the biosorbent once it is no longer useful. Few such studies have been reported for the biosorption/desorption of $\mathrm{Co}^{2+}[9,43]$.

The biosorption capacity of PLEM in the first cycle $\left(46.17 \pm 0.41 \mathrm{mg} \mathrm{g}^{-1}\right)$ was diminished $8.53 \%$ in the second cycle and a cumulative $17.89 \%$ by the end of the third cycle (Figure $5 a$ ), representing significant differences. Hence, the eluent herein employed $(0.1 \mathrm{M} \mathrm{HCl})$ could have damaged the composition and structure of the biosorbent, affecting the sorption sites and reducing the capacity of $\mathrm{Co}^{2+}$ removal from one cycle to the next [55]. However, PLEM maintained an elevated capacity of $\mathrm{Co}^{2+}$ removal throughout the three cycles. During all three cycles, moreover, $\mathrm{Co}^{2+}$ was completely desorbed $\left(E_{D}=100 \%\right)$ from the biosorbent (Figure $5 \mathrm{~b}$ ), evidencing its recyclability. After the end of its useful life, PLEM can be integrated into compost with null impact on the environment because of not containing any $\mathrm{Co}^{2+}$.

(a)

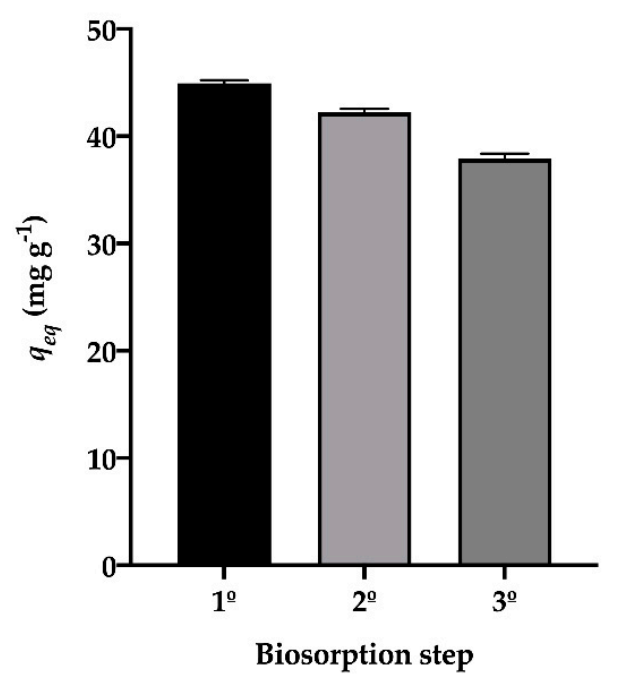

(b)

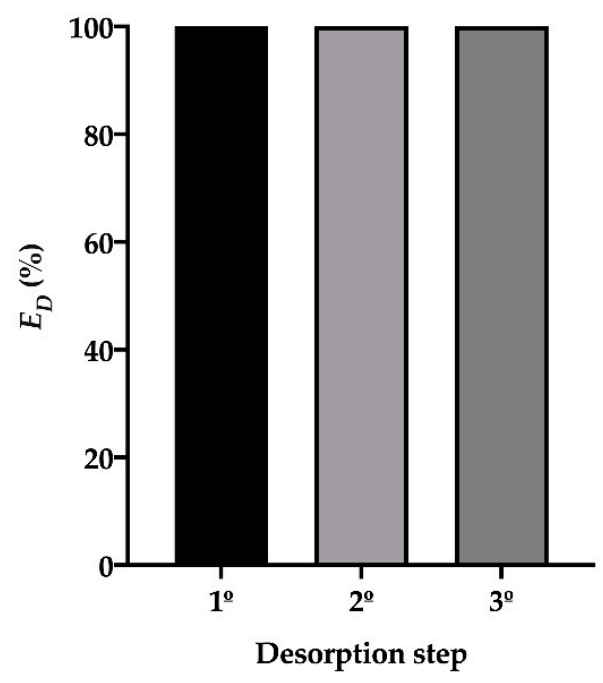

Figure 5. (a) Capacity of biosorption and (b) the percentage of desorption of $\mathrm{Co}^{2+}$ by PLEM during three cycles of biosorption/desorption.

\subsection{Scanning Electron Microscopy Coupled with Energy-Dispersive X-ray Spectroscopy (SEM-EDX)}

The SEM-EDX analysis of PLEM before exposure to $\mathrm{Co}^{2+}$ (Figure 6a) reveals a course and porous surface with agglomerations of the biosorbent. Hence, the surface is characterized by an ample exposure of the active sites for the capture of $\mathrm{Co}^{2+}$. The EDX spectra of PLEM evidences a surface free of $\mathrm{Co}^{2+}$. 

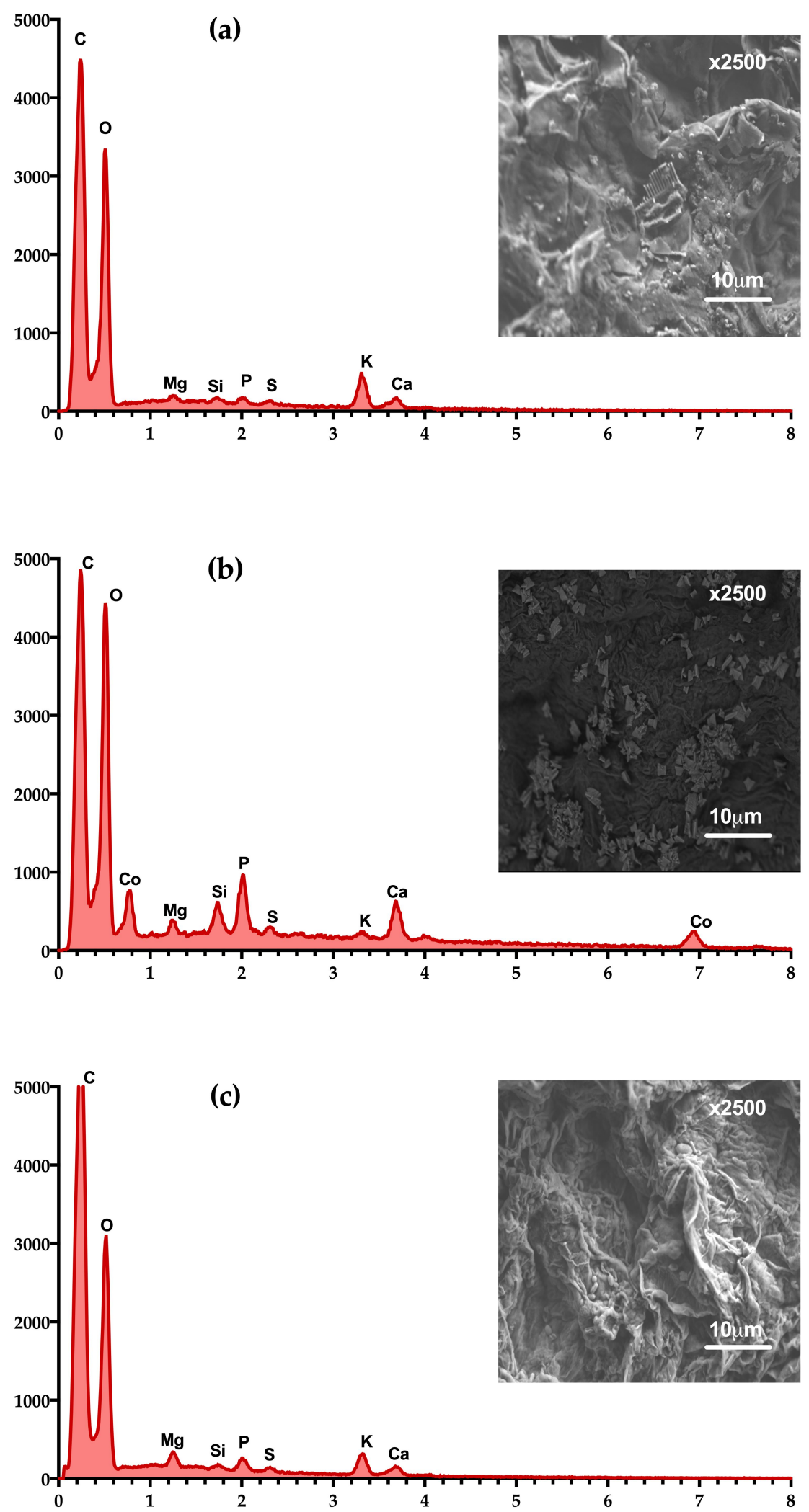

Figure 6. SEM and EDX micrograph of PLEM during the first biosorption/desorption cycle: (a) Before exposure to $\mathrm{Co}^{2+},(\mathbf{b})$ saturated with $\mathrm{Co}^{2+}$, and (c) subsequent to desorption of the biosorbent with $0.1 \mathrm{M} \mathrm{HCl}$. 
The micrograph of PLEM saturated with $\mathrm{Co}^{2+}$ (Figure $6 \mathrm{~b}$ ) shows a more homogenous surface (on which rectangular particles are dispersed) than PLEM prior to contact with $\mathrm{Co}^{2+}$. The following desorption with $0.1 \mathrm{M} \mathrm{HCl}$ (Figure 6c), the appearance of the surface of PLEM is similar to that observed before exposure to $\mathrm{Co}^{2+}$. In the EDX spectrum, two peaks corresponding to $\mathrm{Co}^{2+}$ indicate its presence after the biosorption step (Figure $6 \mathrm{~b}$ ). The absence of such peaks after desorption (Figure $6 \mathrm{c}$ ) evidenced the adequacy of the eluent solution for the total recovery of the metallic ion. Consequently, $\mathrm{HCl}$ was able to regenerate the biosorbent for posterior cycles of biosorption/desorption.

\section{Conclusions}

The results demonstrate that PLEM is an attractive, economical, sustainable, and environmentally friendly material for the removal of $\mathrm{Co}^{2+}$ from aqueous solutions. The capacity of biosorption of $\mathrm{Co}^{2+}$ by PLEM was enhanced by smaller particle size, a greater $\mathrm{pH}$ of the solution, and a higher initial concentration of the metal. The main mechanism of removal of $\mathrm{Co}^{2+}$ from the aqueous solution is physisorption based on electrostatic attraction. While the kinetics of the experimental biosorption data were adequately described by the pseudo-second-order model, the isotherms of biosorption at equilibrium at different temperatures were properly predicted by the Sips and Redlich-Peterson models. According to the thermodynamic study, the biosorption of $\mathrm{Co}^{2+}$ by PLEM is an endothermic and spontaneous process. The best eluent solution for the recovery of both the metal and the biosorbent material was $0.1 \mathrm{M} \mathrm{HCl}$. PLEM can be used for at least three cycles of biosorption/desorption, with a high capacity of biosorption and complete desorption in each cycle, revealing the recyclability of the material, and therefore, the possibility of its economical use. The SEM-EDX analysis confirmed the biosorption of $\mathrm{Co}^{2+}$ by PLEM and the posterior desorption of the plant material by means of its exposure to $0.1 \mathrm{M} \mathrm{HCl}$.

Author Contributions: Conceptualization, L.M.-B. and E.C.-U.; methodology, J.L.R.-L., L.M.-B. and E.C.-U.; software, J.L.R.-L.; validation, J.L.R.-L. and L.M.-B.; formal analysis, L.M.-B. and E.C.-U.; investigation, J.L.R.-L.; resources, L.M.-B. and E.C.-U.; writing-original draft preparation, review and editing, L.M.-B. and E.C.-U.; visualization, L.M.-B.; supervision, L.M.-B. and E.C.-U.; project administration, L.M.-B. and E.C.-U.; funding acquisition, L.M.-B. and E.C.-U. All authors have read and agreed to the published version of the manuscript.

Funding: This research was funded by the Instituto Politécnico Nacional, Secretaría de Investigación y Posgrado, project number: 20201814.

Acknowledgments: The authors are grateful for the technical support provided by the Centro de Nanociencias y Micro y Nanotecnologías, IPN. The CONACyT awarded a graduate scholarship to the coauthor J.L.R.-L., L.M.-B. and E.C.-U. hold grants from EDI-IPN, COFAA-IPN, and SNI-CONACYT. The authors thank Bruce Allan Larsen for proofreading the manuscript.

Conflicts of Interest: The authors declare that they have no conflict of interest.

\section{References}

1. Vilvanathan, S.; Shanthakumar, S. Modeling of fixed-bed column studies for removal of cobalt ions from aqueous solution using Chrysanthemum indicum. Res. Chem. Intermed. 2017, 43, 229-243. [CrossRef]

2. World Health Organization (WHO). Cobalt and Inorganic Cobalt Compounds. In Concise International Chemical Assessment Document 69; Kim, J.H., Gibb, H.J., Howe, P.D., Eds.; WHO: Geneva, Switzerland, 2006; pp. 1-84. Available online: https://apps.who.int/iris/handle/10665/43426 (accessed on 3 August 2020).

3. He, E.-K.; Baas, J.; Van Gestel, C.A. Interaction between nickel and cobalt toxicity in Enchytraeus crypticusis due to competitive uptake. Environ. Toxicol. Chem. 2015, 34, 328-337. [CrossRef] [PubMed]

4. Oguz, E.; Ersoy, M. Biosorption of cobalt(II) with sunflower biomass from aqueous solutions in a fixed bed column and neural networks modelling. Ecotoxicol. Environ. Saf. 2014, 99, 54-60. [CrossRef] [PubMed]

5. Anirudhan, T.; Deepa, J.; Christa, J. Nanocellulose/nanobentonite composite anchored with multi-carboxyl functional groups as an adsorbent for the effective removal of Cobalt(II) from nuclear industry wastewater samples. J. Colloid Interface Sci. 2016, 467, 307-320. [CrossRef] 
6. Fawzy, M.A.; Hifney, A.F.; Adam, M.S.; Al-Badaani, A.A. Biosorption of cobalt and its effect on growth and metabolites of Synechocystis pevalekii and Scenedesmus bernardii: Isothermal analysis. Environ. Technol. Innov. 2020, 19, 100953. [CrossRef]

7. Pipíška, M.; Trajtel'ová, Z.; Horník, M. Compartmentalization of Co and Mn in live cells of Escherichia coli: Investigation using 60Co and 54Mn as radioindicators. J. Radioanal. Nucl. Chem. 2017, 314, 1197-1205. [CrossRef]

8. Pipíška, M.; Richveisová, B.M.; Frišták, V.; Horník, M.; Remenárová, L.; Stiller, R.; Soja, G. Sorption separation of cobalt and cadmium by straw-derived biochar: A radiometric study. J. Radioanal. Nucl. Chem. 2017, 311, 85-97. [CrossRef]

9. Pipíška, M.; Zarodňanská, S.; Horník, M.; Ďuriška, L.; Holub, M.; Safarik, I. Magnetically Functionalized Moss Biomass as Biosorbent for Efficient $\mathrm{Co}^{2+}$ Ions and Thioflavin T Removal. Materials 2020, 13, 3619. [CrossRef] [PubMed]

10. Robalds, A.; Naja, G.M.; Klavins, M. Highlighting inconsistencies regarding metal biosorption. J. Hazard. Mater. 2016, 304, 553-556. [CrossRef]

11. Saman, N.; Tan, J.-W.; Mohtar, S.S.; Kong, H.; Lye, J.W.P.; Mat, H.; Hassan, H.; Mat, H. Selective biosorption of aurum(III) from aqueous solution using oil palm trunk (OPT) biosorbents: Equilibrium, kinetic and mechanism analyses. Biochem. Eng. J. 2018, 136, 78-87. [CrossRef]

12. Moradi, P.; Hayati, S.; Ghahrizadeh, T. Modeling and optimization of lead and cobalt biosorption from water with Rafsanjan pistachio shell, using experiment based models of ANN and GP, and the grey wolf optimizer. Chemom. Intell. Lab. Syst. 2020, 202, 104041. [CrossRef]

13. Muller da Cunha, J.; Klein, L.; Moro Bassaco, M.; Hiromitsu Tanabe, E.; Bertuol, D.A.; Dotto, G.L. Cobalt recovery from leached solutions of lithium-ion batteries using waste materials as adsorbents. Can. J. Chem. Eng. 2015, 93, 2198-2204. [CrossRef]

14. Greenberg, B.M.; Huang, X.-D.; Dixon, D.G. Applications of the aquatic higher plant Lemna gibba for ecotoxicological assessment. J. Aquat. Ecosyst. Health 1992, 1, 147-155. [CrossRef]

15. Arroyave, M.D. La lenteja de agua (Lemna minor L.): Una planta acuática promisoria. Rev. EIA 2004, 1, 33-38. Available online: http://www.scielo.org.co/scielo.php?script=sci_arttext\&pid=S1794-12372004000100004\& lng=en\&tlng=es (accessed on 9 November 2020).

16. Canales-Gutiérrez, Á. Evaluación de la biomasa y manejo de Lemna gibba (Lenteja de agua) en la bahía interior del lago titicaca, puno. Ecol. Apl. 2010, 9, 91-99. [CrossRef]

17. Reyes-Ledezma, J.L. Biosorción de Co(II) a Partir de Soluciones Acuosas por Lemna sp. Master's Thesis, Instituto Politécnico Nacional, Mexico City, Mexico, 2017.

18. Reyes-Ledezma, J.L.; Uribe-Ramírez, D.; Cristiani-Urbina, E.; Morales-Barrera, L. Biosorptive removal of acid orange 74 dye by HCl-pretreated Lemna sp. PLoS ONE 2020, 15, e0228595. [CrossRef]

19. Morales-Barrera, L.; Flores-Ortiz, C.M.; Cristiani-Urbina, E. Single and Binary Equilibrium Studies for $\mathrm{Ni}^{2+}$ and $\mathrm{Zn}^{2+}$ Biosorption onto Lemna Gibba from Aqueous Solutions. Processes 2020, 8, 1089. [CrossRef]

20. Gupta, S.; Sharma, S.; Kumar, A. Biosorption of Ni(II) ions from aqueous solution using modified Aloe barbadensis Miller leaf powder. Water Sci. Eng. 2019, 12, 27-36. [CrossRef]

21. Guo, Z.; Liu, X.; Huang, H. Kinetics and Thermodynamics of Reserpine Adsorption onto Strong Acidic Cationic Exchange Fiber. PLoS ONE 2015, 10, e0138619. [CrossRef]

22. Zhao, Y.; Zhao, X.; Deng, J.; He, C. Utilization of chitosan-clinoptilolite composite for the removal of radiocobalt from aqueous solution: Kinetics and thermodynamics. J. Radioanal. Nucl. Chem. 2016, 308, 701-709. [CrossRef]

23. Ramírez-Rodríguez, A.E.; Reyes-Ledezma, J.L.; Chávez-Camarillo, G.M.; Cristiani-Urbina, E.; Morales-Barrera, L. Cyclic biosorption and desorption of acid red 27 onto Eichhornia crassipes leaves. Rev. Mex. Ing. Química 2018, 17, 1121-1134. [CrossRef]

24. Gramlich, A.; Moradi, A.B.; Robinson, B.H.; Kaestner, A.; Schulin, R. Dimethylglyoxime (DMG) staining for semi-quantitative mapping of $\mathrm{Ni}$ in plant tissue. Environ. Exp. Bot. 2011, 71, 232-240. [CrossRef]

25. Yu, H.; Pang, J.; Ai, T.; Liu, L. Biosorption of $\mathrm{Cu}^{2+}, \mathrm{Co}^{2+}$ and $\mathrm{Ni}^{2+}$ from aqueous solution by modified corn silk: Equilibrium, kinetics, and thermodynamic studies. J. Taiwan Inst. Chem. Eng. 2016, 62, 21-30. [CrossRef]

26. Tofan, L.; Teodosiu, C.; Paduraru, C.; Wenkert, R. Cobalt (II) removal from aqueous solutions by natural hemp fibers: Batch and fixed-bed column studies. Appl. Surf. Sci. 2013, 285 Pt A, 33-39. [CrossRef] 
27. Lee, M.-Y.; Hong, K.-J.; Kajiuchi, T.; Yang, J.-W. Determination of the efficiency and removal mechanism of cobalt by crab shell particles. J. Chem. Technol. Biotechnol. 2004, 79, 1388-1394. [CrossRef]

28. Xu, H.; Liu, Y.; Tay, J.-H. Effect of $\mathrm{pH}$ on nickel biosorption by aerobic granular sludge. Bioresour. Technol. 2006, 97, 359-363. [CrossRef]

29. Suazo-Madrid, A.; Morales-Barrera, L.; Aranda-García, E.; Cristiani-Urbina, E. Nickel(II) biosorption by Rhodotorula glutinis. J. Ind. Microbiol. Biotechnol. 2011, 38, 51-64. [CrossRef]

30. Abbas, M.; Kaddour, S.; Trari, M. Kinetic and equilibrium studies of cobalt adsorption on apricot stone activated carbon. J. Ind. Eng. Chem. 2014, 20, 745-751. [CrossRef]

31. Vijayaraghavan, K.; Yun, Y.-S. Bacterial biosorbents and biosorption. Biotechnol. Adv. 2008, 26, $266-291$. [CrossRef]

32. Volesky, B. Detoxification of metal-bearing effluents: Biosorption for the next century. Hydrometallurgy 2001, 59, 203-216. [CrossRef]

33. Bulgariu, D.; Bulgariu, L. Potential use of alkaline treated algae waste biomass as sustainable biosorbent for clean recovery of cadmium(II) from aqueous media: Batch and column studies. J. Clean. Prod. 2016, 112, 4525-4533. [CrossRef]

34. Mishra, A.; Tripathi, B.D.; Rai, A.K. Packed-bed column biosorption of chromium(VI) and nickel(II) onto Fenton modified Hydrilla verticillata dried biomass. Ecotoxicol. Environ. Saf. 2016, 132, 420-428. [CrossRef] [PubMed]

35. Vilvanathan, S.; Shanthakumar, S. Biosorption of Co(II) ions from aqueous solution using Chrysanthemum indicum: Kinetics, equilibrium and thermodynamics. Process. Saf. Environ. Prot. 2015, 96, 98-110. [CrossRef]

36. Kılıç, M.; Kırbıyık, Ç.; Çepelioğullar, Ö.; Putun, A.E. Adsorption of heavy metal ions from aqueous solutions by bio-char, a by-product of pyrolysis. Appl. Surf. Sci. 2013, 283, 856-862. [CrossRef]

37. Thilagavathy, P.; Santhi, T. Kinetics, Isotherms and Equilibrium Study of Co(II) Adsorption from Single and Binary Aqueous Solutions by Acacia nilotica Leaf Carbon. Chin. J. Chem. Eng. 2014, 22, 1193-1198. [CrossRef]

38. Rangabhashiyam, S.; Anu, N.; Nandagopal, M.S.G.; Selvaraju, N. Relevance of isotherm models in biosorption of pollutants by agricultural byproducts. J. Environ. Chem. Eng. 2014, 2, 398-414. [CrossRef]

39. Hymavathi, D.; Prabhakar, G. Optimization, equilibrium, and kinetic studies of adsorptive removal of cobalt(II) from aqueous solutions using Cocos nucifera L. Chem. Eng. Commun. 2017, 204, 1094-1104. [CrossRef]

40. Imessaoudene, D.; Hanini, S.; Bouzidi, A.; Ararem, A. Kinetic and thermodynamic study of cobalt adsorption by spent coffee. Desalin. Water Treat. 2015, 57, 6116-6123. [CrossRef]

41. Marešová, J.; Pipíška, M.; Rozložník, M.; Horník, M.; Remenárová, L.; Augustín, J. Cobalt and strontium sorption by moss biosorbent: Modeling of single and binary metal systems. Desalination 2011, 266, 134-141. [CrossRef]

42. Demirbaş, E. Adsorption of Cobalt(II) Ions from Aqueous Solution onto Activated Carbon Prepared from Hazelnut Shells. Adsorpt. Sci. Technol. 2003, 21, 951-963. [CrossRef]

43. Lucaci, A.R.; Bulgariu, D.; Ahmad, I.; Bulgariu, L. Equilibrium and Kinetics Studies of Metal Ions Biosorption on Alginate Extracted from Marine Red Algae Biomass (Callithamnion corymbosum sp.). Polymers 2020, 12, 1888. [CrossRef] [PubMed]

44. Vijayaraghavan, K.; Jegan, J.; Palanivelu, K.; Velan, M. Biosorption of cobalt(II) and nickel(II) by seaweeds: Batch and column studies. Sep. Purif. Technol. 2005, 44, 53-59. [CrossRef]

45. Bhatnagar, A.; Minocha, A.; Sillanpää, M. Adsorptive removal of cobalt from aqueous solution by utilizing lemon peel as biosorbent. Biochem. Eng. J. 2010, 48, 181-186. [CrossRef]

46. Lakshmipathy, R.; Sarada, N. Application of watermelon rind as sorbent for removal of nickel and cobalt from aqueous solution. Int. J. Miner. Process. 2013, 122, 63-65. [CrossRef]

47. Vilvanathan, S.; Shanthakumar, S. Removal of Ni(II) and Co(II) ions from aqueous solution using teak (Tectona grandis) leaves powder: Adsorption kinetics, equilibrium and thermodynamics study. Desalin. Water Treat. 2016, 57, 3995-4007. [CrossRef]

48. Dabbagh, R.; Moghaddam, Z.A.; Ghafourian, H. Removal of cobalt(II) ion from water by adsorption using intact and modified Ficus carica leaves as low-cost natural sorbent. Desalin. Water Treat. 2016, 57, 19890-19902. [CrossRef] 
49. Singh, S.A.; Shukla, S.R. Adsorptive removal of cobalt ions on raw and alkali-treated lemon peels. Int. J. Environ. Sci. Technol. 2016, 13, 165-178. [CrossRef]

50. Ahmadpour, A.; Tahmasbi, M.; Bastami, T.R.; Besharati, J.A. Rapid removal of cobalt ion from aqueous solutions by almond green hull. J. Hazard. Mater. 2009, 166, 925-930. [CrossRef]

51. Nadeem, R.; Zafar, M.N.; Afzal, A.; Hanif, M.A.; Saeed, R. Potential of NaOH pretreated Mangifera indica waste biomass for the mitigation of $\mathrm{Ni}(\mathrm{II})$ and $\mathrm{Co}(\mathrm{II})$ from aqueous solutions. J. Taiwan Inst. Chem. Eng. 2014, 45, 967-972. [CrossRef]

52. Bhattacharyya, K.G.; Gupta, S.S. Removal of Cu(II) by natural and acid-activated clays: An insight of adsorption isotherm, kinetic and thermodynamics. Desalination 2011, 272, 66-75. [CrossRef]

53. Ye, W.-M.; He, Y.; Chen, Y.-G.; Chen, B.; Cui, Y.J. Adsorption, Desorption and Competitive Adsorption of Heavy Metal Ions from Aqueous Solution onto GMZ01 Bentonite. In Engineering Geology for Society and Territory; Lollino, G., Giordan, D., Thuro, K., Carranza-Torres, C., Wu, F., Marinos, P., Delgado, C., Eds.; Springer International Publishing: Cham, Switzerland, 2015; Volume 6, pp. 533-536.

54. Zhang, X.; Wang, X. Adsorption and Desorption of Nickel(II) Ions from Aqueous Solution by a Lignocellulose/Montmorillonite Nanocomposite. PLoS ONE 2015, 10, e0117077. [CrossRef] [PubMed]

55. Ronda, A.; Calero, M.; Blázquez, G.; Pérez, A.; Martín-Lara, M.Á. Optimization of the use of a biosorbent to remove heavy metals: Regeneration and reuse of exhausted biosorbent. J. Taiwan Inst. Chem. Eng. 2015, 51, 109-118. [CrossRef]

Publisher's Note: MDPI stays neutral with regard to jurisdictional claims in published maps and institutional affiliations. 